\section{National Policies to Promote Technological Learning and Innovation}

\section{A. Introduction}

This chapter examines the role of national policy in promoting technological learning and innovation in the least developed countries (LDCs). Section B considers briefly what the Governments of the LDCs are currently doing to promote science, technology and innovation. It does so by examining how science and technology issues are treated in poverty reduction strategy papers (PRSPs) and analyzing the findings in the context of current development policy thinking. The evidence shows that, although the LDCs are concerned with promoting sustained economic growth as the basis for poverty reduction, the treatment of technological change as a source of economic growth is generally weak. The rest of the chapter proposes how LDC Governments might rectify this deficiency.

The analysis is based on the commonly accepted insight that processes of technological change in rich countries, where firms are innovating by pushing the knowledge frontier further, are fundamentally different from such processes in developing countries, where innovation primarily takes place through enterprises learning to master, adapt and improve technologies that already exist in more technologically advanced countries. Science, technology and innovation (STI) policies to promote technological development should be different in technologically leading countries from in follower countries, including LDCs. In short, STI policy in LDCs, as in all developing countries, should be geared to technological catch-up with more technologically advanced countries through technological learning and innovation. Innovation in this context occurs when firms commercially apply knowledge which is new to them, even if it is not new to the world or to the country.

The rest of the chapter seeks to clarify what this implies for the design and implementation of STI policy in LDCs. Section C sets out some general considerations on the nature and scope of STI policy. Sections D and E suggest how the catch-up concept can be applied in an LDC context by firstly outlining typical learning and innovation trajectories during catch-up, and secondly considering the implications of those trajectories for LDCs, which are at the early stages of the catch-up process. Section $\mathrm{F}$ raises some issues regarding the capacity of LDC Governments to design and implement policies of the types proposed in the chapter. The conclusion summarizes the major messages of the chapter.

\section{B. How science and technology issues are treated in PRSPs: Recent country experience in comparative perspective}

\section{Recent Country experience}

It is difficult to construct a systematic picture of policies to promote science, technology and innovation in the LDCs. However, many LDC Governments

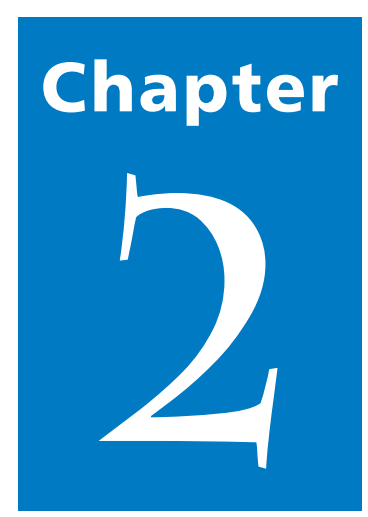

Science, technology and innovation (STI) policies to promote technological development should be different in technologically leading countries from in follower countries, including LDCs. 
Only four of the 11 countries include science and/or technology in their PRSPS as a priority policy for poverty reduction.
Nine of the 11 countries include some reference to initiatives aimed at agricultural research, and all 11 countries include initiatives to promote agricultural extension. prepare PRSPs and these documents give a good indication of the priority which is given to science and technology issues in national policy. Analysis of the PRSPs prepared during the period 2004-2006 in 11 LDCs - including six African LDCs, four Asian LDCs and Haiti - indicates that the incorporation of science and technology issues in PRSPs is generally weak (Warren-Rodriguez, 2007). Nevertheless, some attention has been paid to a number of specific issues, notably applied agricultural research and extension, technical and vocational training, investment in electricity and telecommunications networks, and increased use of information and communication technologies (ICTs), particularly for use of ICTs for better governance.

In particular, the analysis (table 17) shows that:

- Only four of the 11 countries include science and/or technology as priority policy for poverty reduction, with the United Republic of Tanzania and Uganda focusing on the importance of science, and Mozambique and Bangladesh focusing on the importance of technological development.

- Only three of the 11 countries (Bangladesh, Mozambique and the United Republic of Tanzania) include a specific section or paragraph on science and technology issues.

- Only three of the 11 countries (Bangladesh, Lesotho and Sierra Leone) include explicit and specific science and technology initiatives to enhance technology transfer and acquisition through either international trade or foreign direct investment (FDI).

- Only three of the 11 countries (Bangladesh, the United Republic of Tanzania and Uganda) include specific initiatives to support basic research.

- Only four of the 11 countries (Bangladesh, Sierra Leone, Uganda and the United Republic of Tanzania) include specific initiatives for applied research outside agriculture.

- Only four of the 11 countries (Bangladesh, Cambodia, Lesotho and the United Republic of Tanzania) make explicit reference to the need to expand business development services that support technological upgrading efforts by local firms.

- Only three of the 11 countries (Bangladesh, Lesotho and Uganda) include specific science and technology initiatives in all three levels of education - primary, secondary and higher.

- Only six of the 11 countries include policies to promote best practices and quality standards by local firms, typically though the creation and capacitation of local standards and metrology institutions.

There are nevertheless some science and technology-related areas which the PRSPs do address, most notably:

- Seven of the 11 countries include some reference to initiatives aimed at agricultural research, including some, such as Burkina Faso, which include a detailed breakdown of intended activities by crop.

- Nine of the 11 countries include initiatives to promote agricultural extension.

- All 11 countries include specific initiatives to expand technical and vocational education, and all mention its importance.

- All 11 countries identify the need to extend and upgrade electricity networks, and 10 of them also stress the importance of rural electrification.

- Six of the 11 countries acknowledge the importance of improving general telecommunications networks, but only five mention the importance of extending this infrastructure to rural areas. 
Table 17. How S\&T is treated in the PRSPs of selected LDCs

\begin{tabular}{|c|c|c|c|c|c|c|c|c|c|c|c|}
\hline & Bangladesh & Bhutan & $\begin{array}{l}\text { Burkina } \\
\text { Faso }\end{array}$ & Cambodia & Haiti & $\begin{array}{l}\text { Lao } \\
\text { PDR }\end{array}$ & Lesotho & Mozambique & $\begin{array}{l}\text { Sierra } \\
\text { Leone }\end{array}$ & Uganda & $\begin{array}{l}\text { United Rep. } \\
\text { of Tanzania }\end{array}$ \\
\hline $\begin{array}{l}\text { Was S\&T considered a priority } \\
\text { area in the PRSP document? }\end{array}$ & Y & $\mathrm{N}$ & $\mathrm{N}$ & N & $\mathrm{N}$ & W & $\mathrm{N}$ & Y & $\mathrm{N}$ & Y & Y \\
\hline $\begin{array}{l}\text { Is there a specific section/ } \\
\text { paragraph covering S\&T issues? }\end{array}$ & Y & $\mathrm{N}$ & $\mathrm{N}$ & N & $\mathrm{N}$ & $\mathrm{N}$ & $\mathrm{N}$ & Y & $\mathrm{N}$ & $\mathrm{N}$ & Y \\
\hline \multicolumn{12}{|c|}{ Are specific S\&T initiatives included at the level of: } \\
\hline - trade policies & Y & $\mathrm{N}$ & $\mathrm{N}$ & $\mathrm{N}$ & $\mathrm{N}$ & $\mathrm{N}$ & $\mathrm{N}$ & W & Y & W & $\mathrm{N}$ \\
\hline - FDls & Y & $\mathrm{N}$ & $\mathrm{N}$ & $\mathrm{N}$ & $\mathrm{N}$ & W & Y & W & $\mathrm{N}$ & $\mathrm{N}$ & W \\
\hline \multicolumn{12}{|c|}{ Does the PRSP include specific S\&T initiatives in } \\
\hline - primary education & Y & $\mathrm{N}$ & $\mathrm{N}$ & $\mathrm{N}$ & $\mathrm{N}$ & W & Y & $\mathrm{N}$ & $\mathrm{N}$ & $\mathrm{Y}$ & N \\
\hline - secondary education & Y & $\mathrm{N}$ & $\mathrm{Y}$ & $\mathrm{N}$ & $\mathrm{N}$ & W & $Y$ & $\mathrm{Y}$ & $\mathrm{Y}$ & Y & $\mathrm{N}$ \\
\hline - higher education & $\mathrm{Y}$ & $\mathrm{N}$ & $\mathrm{N}$ & $\mathrm{N}$ & $\mathrm{N}$ & W & $\mathrm{Y}$ & $\mathrm{Y}$ & $\mathrm{Y}$ & $\mathrm{Y}$ & Y \\
\hline \multicolumn{12}{|c|}{ Are infrastructural technology concerns treated in the PRSP? } \\
\hline \multicolumn{12}{|l|}{ - electricity networks } \\
\hline - general & Y & Y & Y & Y & Y & Y & Y & Y & Y & Y & Y \\
\hline - rural & Y & $\mathrm{Y}$ & Y & Y & $\mathrm{N}$ & Y & Y & Y & $\mathrm{Y}$ & $\mathrm{Y}$ & $\mathrm{Y}$ \\
\hline \multicolumn{12}{|l|}{ - telecommunication networks } \\
\hline - general & Y & W & Y & Y & Y & W & Y & W & W & $Y$ & W \\
\hline - rural & $\mathrm{Y}$ & $\mathrm{N}$ & Y & $\mathrm{Y}$ & $\mathrm{N}$ & W & $\mathrm{Y}$ & $\mathrm{N}$ & W & $\mathrm{Y}$ & $\mathrm{N}$ \\
\hline \multicolumn{12}{|l|}{ - ICT extension } \\
\hline - general & $\mathrm{Y}$ & $\mathrm{N}$ & N & W & W & W & $\mathrm{Y}$ & $\mathrm{Y}$ & $\mathrm{Y}$ & W & $\mathrm{Y}$ \\
\hline - rural & Y & N.A. & N.A. & $\mathrm{N}$ & $\mathrm{N}$ & W & $\mathrm{N}$ & $\mathrm{N}$ & $\mathrm{Y}$ & $\mathrm{N}$ & N \\
\hline \multicolumn{12}{|c|}{ Are there projects aiming at increasing technological awareness through: } \\
\hline - basic R\&D activities & Y & $\mathrm{N}$ & $\mathrm{N}$ & $\mathrm{N}$ & $\mathrm{N}$ & $\mathrm{N}$ & $\mathrm{N}$ & $\mathrm{N}$ & $\mathrm{N}$ & Y & Y \\
\hline $\begin{array}{l}\text { - applied R\&D activities in } \\
\text { agricultural research }\end{array}$ & Y & W & Y & W & $\mathrm{N}$ & Y & $\mathrm{N}$ & Y & Y & Y & Y \\
\hline $\begin{array}{l}\text { - applied R\&D in industrial/ } \\
\text { engineering research }\end{array}$ & Y & $\mathrm{N}$ & $\mathrm{N}$ & $\mathrm{N}$ & $\mathrm{N}$ & $\mathrm{N}$ & $\mathrm{N}$ & $\mathrm{N}$ & Y & Y & Y \\
\hline $\begin{array}{l}\text { - technical and vocational } \\
\text { education training }\end{array}$ & Y & Y & Y & Y & Y & Y & Y & Y & Y & Y & Y \\
\hline \multicolumn{12}{|c|}{ Are there sector-specific technology extension programmes: } \\
\hline - in agriculture & $\mathrm{Y}$ & $\mathrm{Y}$ & Y & W & W & $\mathrm{Y}$ & $\mathrm{Y}$ & $\mathrm{Y}$ & Y & $\mathrm{Y}$ & Y \\
\hline $\begin{array}{l}\text { - in business development } \\
\text { services }\end{array}$ & Y & W & W & Y & $\mathrm{N}$ & $\mathrm{N}$ & Y & $\mathrm{N}$ & $\mathrm{N}$ & W & Y \\
\hline $\begin{array}{l}\text { - in product standards and } \\
\text { best practices }\end{array}$ & Y & $\mathrm{N}$ & $\mathrm{N}$ & Y & $\mathrm{N}$ & Y & $\mathrm{N}$ & $\mathrm{Y}$ & Y & $\mathrm{Y}$ & N \\
\hline \multicolumn{12}{|c|}{ Source: UNCTAD secretariat based on Warren-Rodriguez (2007). } \\
\hline Note: $\quad \mathrm{Y}=$ yes, $\mathrm{N}=$ no, $\mathrm{W}$ & weak, N.A. $=$ & not avai & lable. & & & & & & & & \\
\hline
\end{tabular}

- However, nine of the 11 countries include specific initiatives to apply ICT to improve public administration and public service delivery.

- Seven of the 11 countries intend to promote renewable energy resources (e.g. solar and wind power).

These results are important, as the sample of PRSPs is representative of the latest generation of PRSPs in LDCs. As shown in the Least Developed Countries Report 2004, the PRSP approach has evolved considerably since it was first introduced at the end of 1999. In particular, there has been a shift away from an exclusive emphasis on increasing social sector expenditures in the context of debt relief, towards poverty reduction strategies whose first pillar is to ensure strong and sustainable growth (see UNCTAD, 2004: 272-273). With this renewed focus on economic growth as the basis for poverty reduction, there is greater concern with sources of economic growth. One would expect that this would logically lead to consideration of the role of technological progress. As we shall discuss in more detail below, most major growth theories identify technological change as being at the heart of growth processes. But as the evidence above shows, this has not occurred. In short, the new focus on economic growth as the basis of poverty reduction in the latest generation of PRSPS has not generally been associated with a focus on technological progress as a key source of economic growth. ${ }^{1}$

The new focus on economic growth as the basis of poverty reduction in the latest generation of PRSPS has not generally been associated with a focus on technological progress as a key source of economic growth. 


\section{A COMPARATIVE PERSPECTIVE}

The weak treatment of technological change reflects the marginalization of technology policies within structural adjustment programmes of the 1980s and 1990s, and the omission of technology issues from the PRSP approach which replaced such programmes in 2000.

Technological development was an integral, though very imperfect, aspect of efforts to promote development in LDCs prior to structural adjustment.

\section{Technology policy was not considered as part of structural adjustment} programmes. Key institutions and incentives for agricultural and industrial development which were created prior to the1980s as part of development plans were dismantled as economic policy moved decisively in the direction of economic liberalization and privatization.

The introduction of the PRSP approach in late 1999 has reinforced the marginalization of science and technology issues in LDC policy processes.
Most LDCs began their structural adjustment a little later than other developing countries. However, since 1988, two thirds of the LDCs have been intensively engaged in reform processes (UNCTAD, 2000: part II, chapter 4). Although there were some problems of implementation, the process of economic liberalization was pushed by policy conditionality associated with aid and debt relief programmes, and pulled by the belief of many policymakers in the 1990s that liberalization was the best way to ensure the benefits of globalization reached LDCs. Whatever the balance of impulses, many LDCs have undertaken rapid and comprehensive reforms, which have continued during the PRSP era. This has created a totally different policy environment from that at the end of the 1980s. A telling indicator of the depth of reforms is the fact that two thirds of the LDCs had an open trade regime according to the International Monetary Fund's index of trade restrictiveness in 2002, and the LDCs had actually undertaken more trade liberalization than other developing countries (UNCTAD, 2004: part II, chapter $5)$.

Technological development was an integral, though very imperfect, aspect of efforts to promote development in LDCs prior to structural adjustment. Thus, for example, many LDCs had agricultural marketing boards which were intended to serve a variety of functions, including research and the provision of services which supported technological upgrading of export crops. But technology policy was not considered as part of structural adjustment programmes. Key institutions and incentives for agricultural and industrial development which were created prior to the1980s as part of development plans were dismantled as economic policy moved decisively in the direction of economic liberalization and privatization.

The decline and fragmentation of science and technology infrastructure (research institutes, universities and technology policy coordination bodies) were particularly severe in African LDCs in the 1990s (see UNESCO, 2005). In Bangladesh, a broad set of publicly funded research and development (R\&D) institutes has been maintained, and Nepal, which established a Ministry of Science and Technology in 1996, has continued to support technological development in its five-year planning process. But in both cases, low levels of public funding for research institutes are a problem (UNESCO, 2005: 257-259), and in Bangladesh, as the case study in chapter 3 of this Report shows, the disarticulation between public research and development institutes and productive sectors remains a key constraint on learning at the enterprise level. ${ }^{2}$

The introduction of the PRSP approach in late 1999 has reinforced the marginalization of science and technology issues in LDC policy processes. The approach is based on the important principle of domestic ownership and there has been a genuine effort to encourage the emergence of home-grown policies which can provide the basis for a more effective partnership with donors. However, given weak state capacity and also the tension between policy conditionality and domestic ownership, most PRSPs tend to be concerned with strengthening and deepening the earlier economic reform processes. They embody so-called second generation reforms, which pay particular attention to social allocation of public resources and seek improved governance, including reducing corruption and promoting an overall improved investment climate. Promoting technological change is not part of the vision, and it is conspicuously absent from the PRSP 
Source Book of the World Bank, which is intended as a guide to policymakers (Klugman, 2002).

It is important that LDC Governments give much more attention to technological progress as a source of economic growth. This requires a more radical rupture from past structural adjustment policies. As the World Bank (2005) recognizes, the key lesson from economic reforms of the 1990s was not that they failed to integrate social considerations and poverty reduction issues. Rather, it was that they failed to promote economic growth. In particular:

- Economic reforms "enabled better use of existing capacity but did not provide sufficient incentives for expanding that capacity" (ibid., 10).

- They "often mistook efficiency gains for growth" (ibid., 11).

- They "exaggerated the gains from improved resource allocation and their dynamic repercussions, and proved to be both theoretically incomplete and contradicted by the evidence" (ibid., 11).

- "Expectations that gains in growth would be won entirely through policy improvements were unrealistic" (ibid., 11).

- "Means were often mistaken for goals - that is, improvements in policies were mistaken for growth strategies, as if improvements in policies were an end in themselves" (ibid., 11).

From this diagnosis, it is argued that:

- "Going forward, the pursuit of policy reforms for reform's sake should be replaced by a more comprehensive understanding of the forces underlying growth" (ibid., 11).

- "Removing the obstacles that make growth impossible may not be enough: growth-oriented action, for example, on technological catch-up, or encouragement of risk-taking for faster accumulation, may be needed" (ibid., 11).

From the perspective of this Report, it is important that LDC Governments elaborate development strategies which are designed to promote sustained economic growth and poverty reduction through the development of their productive capacities. PRSPs, which often now function as medium-term public expenditure frameworks, can be embedded within such long-term development strategies. Technological development issues, as well as trade development issues, should be integral aspects of the broader development strategy and can be integrated within poverty reduction strategies through the development strategies.

If LDCs ignore the need for adopting policies to promote technological progress as a basic source of economic growth, they are likely to be increasingly marginalized within the global economy. The problem of marginalization is not simply a question of the very low level of technological development in LDCs indicated in the introduction of this Report. It also reflects the fact that promoting technological change is at the heart of Organisation for Economic Co-operation and Development (OECD) efforts to promote economic growth in LDCs (Weiss, 2005). It also has been a central component of development strategies in the most successful developing countries and is becoming important in more and more developing countries.

Policies to promote technological catch-up were an integral component of developmental success in East Asian developing countries (UNCTAD, 1994; Akyuz, 1998; Nelson and Pack, 1999), and successful models are being adapted in

If LDCs ignore the need for adopting policies to promote technological progress as a basic source of economic growth, they are likely to be increasingly marginalized within the global economy. 
The broad revival of interest in policies to promote technological change, partly inspired by the East Asian success, is indicative of wide restlessness to find a new, post-Washington-Consensus policy model as well as of the intuition that it is in this area - promoting technological change - that it is possible to find more effective policies to promote growth and poverty reduction. follower countries such as Malaysia and Viet Nam. In Latin America, science and technology policies were marginalized in the early period of structural reforms. But the Economic Commission for Latin America and the Caribbean (ECLAC) has, since 1990, been advocating the adoption of mesolevel and microlevel productive development policies alongside macroeconomic reforms (see for example, ECLAC, 1990, 1995, 2004). These ideas are now taking concrete shape as more and more countries are adopting productive development policies, including policies to promote STI (Peres, 2006). Some argue that what is emerging is a new "openeconomy industrial policy", in which proactive measures are used to promote infant export industries rather than infant import-substitution industries (see Melo, 2001; Schrank and Kurtz, 2005). A recent review of these new industrial policies has concluded that although these policies are very widespread in Latin America, they are as yet "timid and inconsistent" (Melo and Rodriguez-Clare, 2006: 54), partly owing to negative associations with old-style import-substitution industrial policy and partly owing to budgetary constraints and institutional weaknesses. Moreover, the effectiveness of the new open-economy science and technology policies has also been questioned (Cimoli, Ferraz and Primi, 2005). However, Schrank and Kurtz $(2005,2006)$ provide empirical evidence which suggests that the new open-economy industrial policy is actually accelerating export growth rates in countries where they are being most intensively applied. Moreover, Melo and Rodriguez-Clare (2006: 57) argue that the current phase is best understood as a policy learning phase through which "productive development policies can develop their potential to effectively contribute to the goals of growth and modernization".

Similarly, in Africa there has recently been an important surge of interest at the regional level in science and technology issues, with the New Partnership for Africa's Development (NEPAD) and the African Union both promoting new regional initiatives to revive science and promote centres of excellence (NEPAD, 2005). Technological development was actually at the heart of the African solution to the economic crisis of the 1970s — as set out in the Lagos Plan of Action before it was overtaken by the structural adjustment programmes, which focused on getting price incentives right. These initiatives are thus returning to a promising road already identified but not yet travelled.

In retrospect, it is clear that, although structural adjustment programmes addressed some real policy failures, they threw out the baby with the bathwater. The broad revival of interest in policies to promote technological change, partly inspired by the East Asian success, is indicative of wide restlessness to find a new, post-Washington-Consensus policy model as well as of the intuition that it is in this area - promoting technological change - that it is possible to find more effective policies to promote growth and poverty reduction. If LDCs do not participate in this policy trend, they will be increasingly marginalized in the global economy, where competition increasingly depends on knowledge rather than the simple possession of natural resources.

\section{The nature and scope of ST policies}

Although the weak focus on technological change within national policies to promote economic growth and poverty reduction is striking, some might argue that STI policies are a luxury which LDCs cannot afford at their stage of development. This view may partly be based on a misunderstanding of the role of technological change in development. But it also could be founded on a narrow conception of a science, technology and innovation policy. In the past, a science policy was often associated with the funding of scientific research and the 
training of scientists. Similarly, technology policy has been closely associated with the development of specific technologies, particularly to support new high-tech industries. However, these notions of science and technology policies have now been superseded by a broader notion of what STI policy is and how it can be implemented. This section sets out features of this broader notion.

\section{LNEAR VERSUS SYSTEMS MODELS OF INNOVATION}

In the past, the scope of STI policy has been highly influenced by a linear model of innovation which suggests that basic science leads to applied science, which in turn causes innovation. The policy implication of this science push model of innovation is simple. According to Arnold and Bell (2001: 5), "If you want more innovation (and therefore economic development), you should fund more science".

This science-push model of innovation was very influential in the design of technology policies in OECD countries in the 1950s and 1960s, and it has also influenced the approach to science and technology in developing countries and LDCs. For example, in the 1960s many African LDCs established research and development (R\&D) institutes as a means of acquiring technology. At the same time, they set up policy institutions such as national research councils or ministries for science and technology, and money budgeted for science and technology was spent on these R\&D institutes and policy institutions. In this approach, "S\&T policy was interpreted to mean R\&D policy" (Oyelaran-Oyeyinka, 2006: 45).

There are various problems with the science-push model of innovation. One glaring weakness has been the lack of relevance of public research institutions to the needs of the productive sectors and the irrelevance of scientific research efforts to commercial market needs. This weakness is quite apparent in the LDCs, where "sparse, often disconnected R\&D activities have little if any links with the needs of domestic enterprises or farmers organizations" and where the dearth of linkages between formal public research institutes and domestic production dissipate the considerable inputs already invested over the years" (UNCTAD, 2006a: 251). Evidence from investment climate surveys indicates that in recent years only 0.4 per cent of the companies considered universities or public institutes the most important channel for technology acquisition, and only 3.4 per cent of the firms reported that universities and public institutes were their first-most, second-most or third-most important source of technology acquisition (ibid., table 35).

The weakness of the supply-push model has led to an alternative approach - a demand-pull model of innovation. In essence, this retains a linear model of innovation but the initial impulse for innovation does not come from sciencepush but rather from demand-pull. Instead of the public sector being the main science and technology provider, the expressed demands of the private sector are meant to provide the motor for technological change. Recent technology policies in Latin America reflect this approach (Cimoli, Ferraz and Primi, 2005) and illustrate an attempt to achieve greater articulation between public sector technological agencies and the private sector. This has involved a shift in the science and technology priorities of the public agencies from basic research to the provision and commercialization of technological services, mainly oriented to support production process management and quality control. Moreover, technology funds have been established to subsidize technological development projects of private firms and training. They have also been used to promote the development of private-sector technological services providers, thus facilitating the emergence of a technological services market.

\section{There are various problems with the science-push model of innovation. One glaring weakness has been the lack of relevance of public research institutions to the needs of the productive sectors and the irrelevance of scientific research efforts to commercial market needs.}

Evidence from investment climate surveys in LDCs indicates that in recent years only 0.4 per cent of the companies considered universities or public institutes the most important channel for technology acquisition. 
In this systems model of innovation, the ability and propensity of an enterprise to innovate not only depends on its access to knowledge from research institutes or technology services centres (pushed or pulled), but also on many other factors including...

... access to finance; access to human resources; adequate basic physical infrastructure; firm-level capabilities; inter-firm linkages and collaboration; general business services; demand conditions; and the framework conditions including the investment climate, general cultural propensity towards entrepreneurship and levels of literacy.
Both the supply-push and demand-pull models of innovation are now viewed as oversimplified views of how innovation occurs (Arnold and Bell, 2001). As a result, a different model of innovation has emerged which suggests that innovation depends on the existence of a variety of agents and institutions (much greater in scope than technology providers and technology users) and that the effectiveness of innovation depends on the interactions between these agencies and institutions.

In this systems model of innovation, the ability and propensity of an enterprise to innovate not only depends on its access to knowledge from research institutes or technology services centres (pushed or pulled), but also on many other factors including: access to finance; access to human resources; adequate basic physical infrastructure; firm-level capabilities; inter-firm linkages and collaboration; general business services; demand conditions; and the framework conditions including the investment climate, general cultural propensity towards entrepreneurship and levels of literacy. There is no longer a single source of innovation (scientific research) but multiple sources, including interactions among enterprises and sectors.

The systems approach to innovation has become widely accepted within OECD countries (OECD, 1997). The focus for STI policies is upon improving "national innovation systems". Such systems are defined as "that set of distinct institutions which jointly and individually contributes to the development of diffusion of new technologies and which provides a framework within which Governments form and implement policies to influence the innovation process. As such it is a system of interconnected institutions to create, store and transfer the knowledge, skills and artifacts which define new technologies" (Metcalfe, 1995). The main elements of such a system are illustrated schematically in chart 7.

Chart 7. Major components of a national innovation system

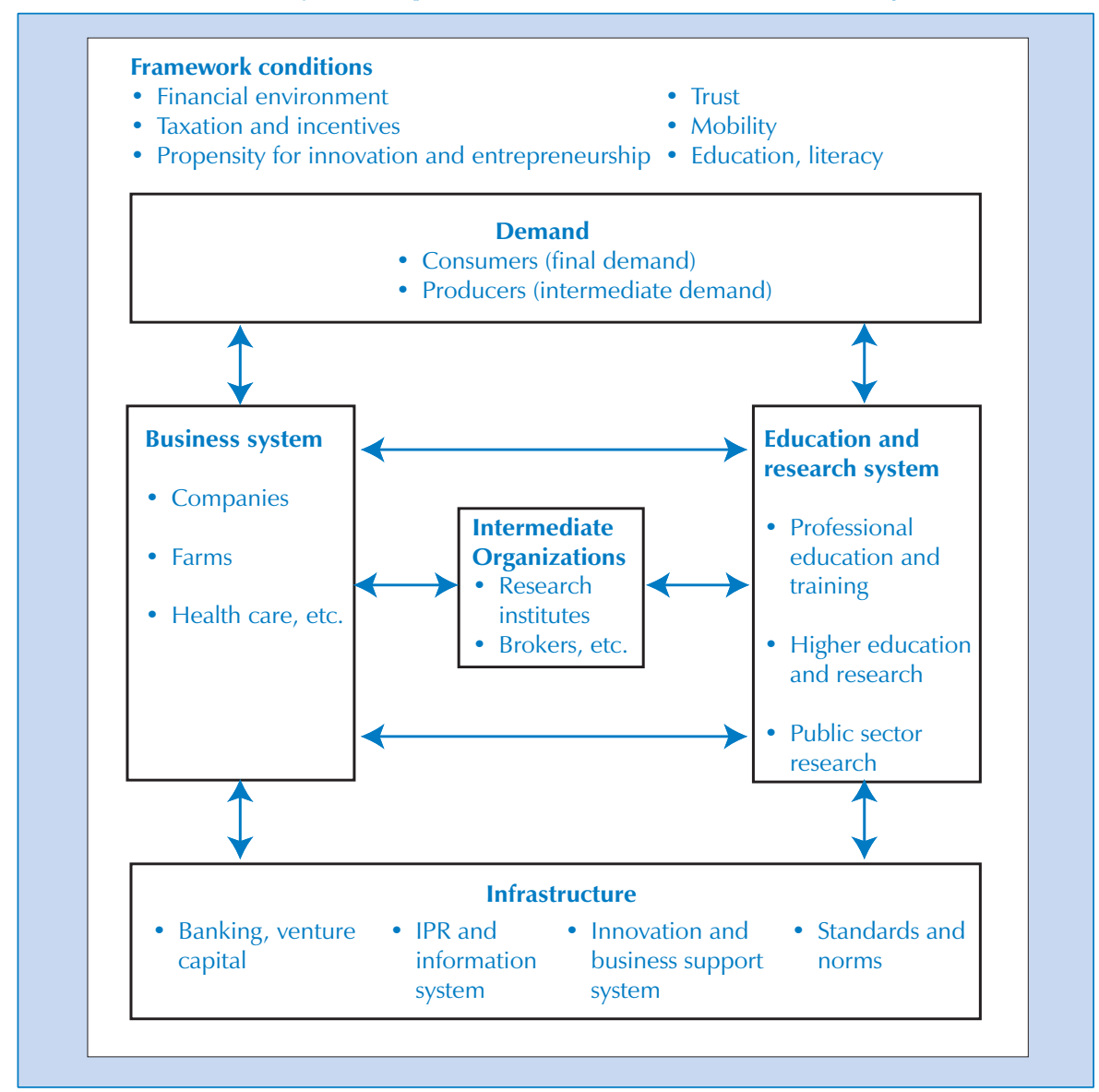

Source: Arnold and Bell (2001) 
It is important that, in their approach to the design and implementation of STI policy, LDC Governments also adopt a systems approach. But in this Report, it is suggested that it may be premature to seek to establish national innovation systems. Rather, the aim should be to develop local and sectoral innovation systems, as illustrated in box 1 , and to increase the absorptive capability of domestic knowledge systems. The latter idea will be discussed in more detail below.

\section{Box 1. Chilli production in Bangladesh: how the innovation system works in practice}

The fertile Jamalpur chars — temporary islands formed by siltation in river deltas — in Bangladesh are well known for their high-quality chilli production. Although the chars are very fertile, there is a lack of basic infrastructure and the chilli-growers often lack market information and have weak linkages with external actors.

To strengthen the sustainable innovation systems linked to local chilli production, the United Kingdom Department for International Development is funding the Crop Post-Harvest Research Programme, which aims to identify and strengthen linkages among all actors involved in the chilli supply chain.

Box chart 1 shows that all the actors involved in enhancing the local innovation systems are closely related. The arrows in the chart refer to the flows of goods and knowledge among these actors. The strongest links between the char-dwellers and the mainland actors are to be found in the private sector. Information from the private sector and the public extension services is passed on to the local char-dwellers by so-called input dealers. Local middlemen provide market access for local products, although national chilli processors and retailers are also starting to develop direct links with the char-dwellers (highlighted by the dashed line). Non-governmental organizations act as promoters, while the research team builds linkages between the public and private sectors and locals. The research team bridges the gap between the private-sector research institute, which is currently introducing new chilli seed varieties, and the other actors. It is also providing training to private- and public-sector agents to make this system viable and sustainable on its own.

The actors need to be: (a) flexible, in order to adapt to the evolving needs of the partners; (b) accountable to other actors; and (c) interactive, as the evolution of activities over time and among the actors is considered to be key to the success of intervention in technology markets.

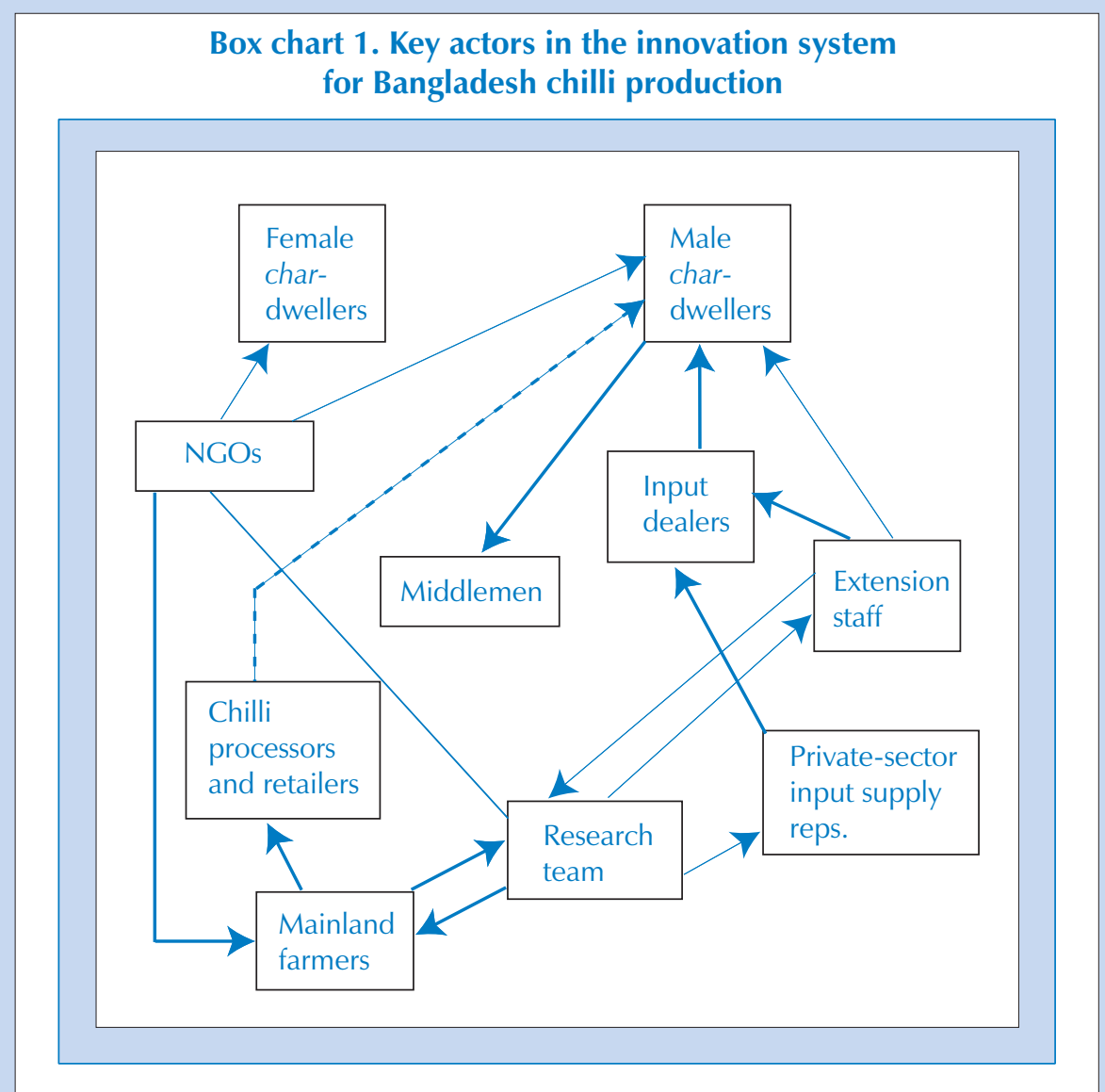

Source: Biggs, S. and Hatsaert, H., 2004. 


\section{EXPUCITAND IMPUCITINSTRUMENTS OF STI POUCY}

The systems model of innovation has important implications for the scope of public action. The supply-push model of innovation leads to a narrowlydefined STI policy which focuses on scientific research. The systems approach to innovation rather suggests that innovation depends upon a large number of

It is important that, in their approach to the design and implementation of STI policy, LDC Governments also adopt a systems approach.

The systems approach to innovation suggests that innovation depends upon a large number of policies and institutions. policies and institutions. It implies that the instruments of STI policy should not only include measures to stimulate the supply side of technology development, but also measures to stimulate the demand for technology development, measures to strengthen the links between supply and demand, and measures which address framework conditions.

Table 18, which builds on Dodgson and Bessant (1996), summarizes some of the relevant STI policy tools. At the top of the table are explicit measures which are concerned with human resources development for science and technology, public science and technology infrastructure, and policies to affect technology imports. Public science and technology infrastructure includes such institutions as public research centres, technology advisory centres, agriculture and industrial extension agencies, and business support services, which are all concerned with the supply of knowledge within domestic knowledge systems. At the bottom of the table are implicit measures which affect the willingness and ability to undertake the investments, in both physical capital and human skills, necessary for innovation.

The implicit measures are fairly standard and include public physical infrastructure investment; financial and fiscal policies which increase the incentive for investment and innovation; trade policy and competition policy; public enterprises and public procurement; and regulation, notably in relation to intellectual property rights.

What is particularly critical in this regard for LDCs is that both physical infrastructure and financial policies are central implicit STI policy instruments. With regard to physical infrastructure, public investment is necessary to crowd in

\begin{tabular}{|c|c|}
\hline \multicolumn{2}{|c|}{ Table 18. Explicit and implicit instruments of STI policy } \\
\hline Human resource development & $\begin{array}{l}\text { General education systems, universities and polytechnics, technical and vocation, education and } \\
\text { training, apprenticeship schemes }\end{array}$ \\
\hline Science and technology infrastructure & Public research laboratories, research associations, research grants, technology centres \\
\hline Information & Networks, advisor centres, consultancy services, specialist libraries, databases \\
\hline Technology import policy & FDI policy, licences \\
\hline Implicit policy instruments & Examples \\
\hline Physical infrastructure & Power, roads, communication \\
\hline Direct financial support & Grants, subsidies, loans, provisions of equipment or services, loan guarantees \\
\hline Indirect financial support & Schemes encouraging investment in innovation, venture capital \\
\hline Trade & Trade agreements, tariffs, currency regulation \\
\hline Public procurement & Central or local government purchasing and contracts, R\&D contracts \\
\hline Taxation & Company, personal, indirect and payroll taxation, tax allowances \\
\hline Regulation & $\begin{array}{l}\text { Patents, regulations (e.g., in environmental control), inspectorates, monopoly and anti-trust } \\
\text { legislation }\end{array}$ \\
\hline Public enterprise & $\begin{array}{l}\text { Innovation by publicly-owned industries, use of these as pioneering facilities, establishment of } \\
\text { new industries }\end{array}$ \\
\hline Political & $\begin{array}{l}\text { Planning, regional policies, honours and awards for innovation, encouragement of mergers or } \\
\text { joint ventures }\end{array}$ \\
\hline Public services & $\begin{array}{l}\text { Procurement, maintenance, supervision, and innovation in public services such as } \\
\text { telecommunications, transport and health care }\end{array}$ \\
\hline
\end{tabular}


private sector investment and innovation. But innovation is a risky process which often involves capital investment and resource mobilization. Access to finance and adequate financial incentives are conditions without which innovation will not take place. In this regard, development banks are particularly important at early stages of a catch-up process and venture capital funds become important later. A variety of fiscal policies are used to stimulate pioneer investments, including tax holidays, accelerated depreciation allowances, investment tax credits, duty-free imports of capital goods and reduced capital goods. Moreover, beyond measures to ensure that entrepreneurs have access to finance - which might involve, for example, special agencies for SMEs or even the establishment of technology banks for bigger projects - pioneer investors can benefit from credit subsidies or loan guarantees, which partially socialize risks.

Trade policy is also important for the innovation process. In the classic case of technology acquisition in the Republic of Korea, protectionist measures using temporary tariff barriers were combined with export promotion measures to support initial acquisition of technology and implementation of production and then to encourage upgrading (Kim, 1980). More recently, there are important lessons for LDCs from the cases of Viet Nam and Mauritius and a number of other successful developing countries which have adopted a gradual approach to trade liberalization. Competition policy also matters, and policy may be designed to achieve a balance between the beneficial effects of competitive pressures together with those arising from coordination. Thus, the creation of dynamic and innovative clusters of economic activity is now regarded as a critical feature of innovation policies in many countries. Regulation policy, in particular in relation to intellectual property rights (IPRs), is also important, and will be discussed in chapter 3. Public procurement can be a powerful source of demand for innovation and public sector enterprises can play a role in stimulating innovation. This can occur, for example, in the example which public service organizations set in their innovative practices. Sometimes, too, Governments may have to set up demonstration enterprises, which can show the viability and profitability of new activities. The activity of the Chilean Economic Development Agency (CORFO) and Fundación Chile all exemplify this.

\section{Oம INDUSTRIAL POUCY VERSUS NEW INNOVATION POUCY}

Articulating this array of instruments of STI policy in a way which stimulates firms and farms to undertake innovation, in the sense of introducing products and production processes which are new to them, is a complex task. In the past, explicit technology policies were often implemented as part of an industrial policy which sought to develop strategic sectors through a combination of tariff protection, direct subsidies and prohibitions on certain kinds of technology transfer. These policies worked well in some successful East Asia countries, where firms were subject to performance criteria or effective monitoring in line with specified development targets (see Amsden, 2001). But in many other cases, industrial policy - and the associated technology policy - became hostage to special interest groups and resulted in wasted scarce resources. Nevertheless, as noted earlier in this chapter, there has been a revival of interest in industrial policy in recent years. The new industrial policy is very different from the old industrial policy, in that it focuses on promoting entrepreneurship and innovation through a mixed, market-based model with the Government and private sector working closely together. This new approach to industrial policy can offer significant insights for Governments in the design and implementation of STI policies, which are relevant not only within manufacturing, but more generally in agriculture, industry and services.

Trade policy is also important for the innovation process.

The new industrial policy which focuses on promoting entrepreneurship and innovation through a mixed, market-based model with the Government and private sector working closely together can offer significant insights for Governments in the design and implementation of STI policies. 
In the new industrial policy - which is sometimes renamed an entrepreneurial policy or an innovation policy — the State acts as a facilitator of learning.

\section{Government policy is directed towards addressing systemic failures which occur in knowledge accumulation and technology development.}

\section{Government policy should play a catalytic role in the sense that policies should over time increasingly stimulate market forces to promote innovation and learning.}

In the new industrial policy - which is sometimes renamed an entrepreneurial policy or an innovation policy - the State acts as a facilitator of learning. The private sector is perceived as the main agent of change. But the Government facilitates the process of entrepreneurial search and discovery for viable new economic activities (see Rodrik, 2004; Kuznetsov and Sabel, 2005). There are significant risks involved, which implies the need for a partnership and synergies with the public sector to socialize risks. Coordinated action is also often necessary, as returns from the investment of one entrepreneur depend on investments in other sectors. The state catalyzes and coordinates private investment and innovation through market-based incentives aimed at reducing risks and sharing benefits.

This approach to STI policy has a number of features. First, it is based on a strategic vision of national priorities for economic and technological development, which must be elaborated within the broader context of social and economic objectives.

Second, Government policy is directed towards addressing systemic failures which occur in knowledge accumulation and technology development. Important sources of market failure - incomplete appropriability, uncertainty and indivisibilities - have long been recognized in processes of scientific research (Arrow, 1962). But the systems approach to innovation draws attention to wider systems failures in both market and non-market institutions. The most basic one is the low level of firm capabilities. But low levels of non-market interactions between actors in the system may also contribute to poor innovative performance. Against this background, public action should seek to enhance the performance of the market system and to create the conditions needed to ensure that the economic system achieves socially desirable goals which would be unobtainable through market forces alone. Such socially desirable goals might include the endogenization of certain technological activities (such as R\&D or training in design and engineering) within private firms, or the promotion of economic diversification so that the economy is not locked into unstable economic structures which do not generate sufficient job opportunities. For countries at the earliest stages of the catch-up process, the case for public action is particularly strong. There are various system failures:

- Investment and innovation are discouraged by fundamental uncertainty. The costs of investment and innovation are high but benefits are uncertain and come later.

- Investment and innovation are also discouraged when all costs are borne by the firm itself but externalities mean that others gain part of the benefits.

- There are also major coordination risks when the profitability of investment and innovation by one economic agent depends on other agents also undertaking investment.

Third, government policy should play a catalytic role in the sense that policies should over time increasingly stimulate market forces to promote innovation and learning. Such policies have been called "market-stimulating" technology policies (Lall and Teubal, 1998: 1382). They encompass measures to stimulate the development of markets for technology support services.

Fourth, technology policies should encompass a mixture of functional, horizontal and vertical policies (ibid., 1370). Functional policies are intended to improve the working of markets economy-wide, in particular in factor markets, without favouring particular sectors or activities. Vertical policies are sectoralspecific, and seek to promote technological learning and innovation within particular sectors. Horizontal policies are concerned with promoting generic 
technological learning and innovation activities within firms that are socially desirable and cross-sectoral (Teubal 1996).

Finally, incentives and public institutions which promote learning and innovation should be carefully designed to ensure their effectiveness. Rodrik (2004) summarizes a number of good practices as follows:

- Incentives should be provided only to activities which are new to the national economy (that is, pioneer activities) and which thus fosters diversification.

- There should be clear benchmarks/criteria of success and failure, and winners should be rewarded and losers abandoned.

- There must be a built-in sunset clause; thus, public support will be withdrawn after an appropriate amount of time has elapsed.

- Public supportshould target activities (such as learning design and engineering skills), not sectors, and although these activities may be sector-specific, they should be cross-cutting as far as possible.

- Any activities that are subsidized must have a clear potential of providing spillovers and demonstration effects.

- Support measures should be designed, implemented and monitored by agencies with demonstrated competence.

- Such agencies should be politically accountable and closely monitored.

- The agencies must maintain clear lines of communication with the private sector.

- Mistakes will be made, so transparency is important.

- Support measures must be adaptable to take account of the evolution of the industries concerned.

\section{Applying the catch-up concept in an WC context: Typical leaming and innovation trajectories}

STI policies in LDCs need to be founded on a strategic vision for national economic development and integrated within their national development strategies. In general terms, such strategies will involve concerted efforts to increase domestic value-added, productivity and international competitiveness by increasing the knowledge content of economic activity and to promote diversification through learning and innovation. But this Report argues that the underlying strategic objective of policymakers should be to promote technological catch-up with more technologically advanced countries.

The focus on technological catch-up as a basic objective can help policymakers because "the "gap" with the state of technology in leader countries helps define the capabilities that are needed and the direction in which resources should be allocated" (Arnold and Bell, 2001:19). But policy analyses of the catch-up process have gone further and identified typical trajectories of learning and innovation which occur during the catch-up process. This is particularly important for LDCs, as catch-up is a process which takes time and involves cumulative learning in which earlier, simpler capabilities and activities provide the basis for developing more advanced capabilities and activities. An important lesson from successful experience is that development strategies should adopt this step-by-step process, 
and STI policies which are an integral part of such strategies should evolve during the process of technological catch-up as business capabilities and domestic knowledge systems develop and as the structure of the national economy changes. The typical learning and innovation trajectories during catch-up provide the basis for identifying how strategic priorities, incentives and institutions of STI policy can change over time as technological catch-up occurs.

In broad terms, analysts have identified two different stages of the catch-up process: (a) an early catch-up stage in which simple technologies are adopted in mature low-tech, and medium-tech industries; and (b) a late catch-up stage in which more complex technologies are adopted in medium and high tech industries which are in a consolidation phase where process technology is still changing rapidly (see Kim and Dahlman, 1992; Pack, 2000; Amsden and Chu, 2003). The late catch-up stage is relevant for countries which have already established simple

The typical learning and innovation trajectories during catch-up provide the basis for identifying how strategic priorities, incentives and institutions of STI policy can change over time as technological catch-up occurs. industries but do not operate at the world technological frontier and no longer can compete on the basis of low wages and unskilled labour.

The two stages of the catch-up process are distinguished by the complexity of the types of industries which are developing. However, by focusing on individual industries within each stage, analysts have gone further and identified three broad phases of learning and innovation through which a new sector develops within a country. These are: firstly, the initiation of production by importing foreign technology and implementing production; secondly, local diffusion of new products and processes as more firms adopt the technology; and thirdly, industrial upgrading through incremental technological improvements to process and product design, and also associated marketing improvements. For some industries, such industrial upgrading is associated with a shift from producing for local markets to producing for export markets. This three-phase sequence was initially observed by Kim (1980) and has been found to apply in a range of industries in East Asia, such as garments, machine tools and motorcycles (Otsuka, 2006) (see chart 8). It should be noted that the phases can overlap somewhat and that they "are not necessarily sequential" (Kim and Dahlman, 1992). However, successful assimilation of foreign technologies within a country involves all three phases - initial implementation by pioneer investors, local diffusion and upgrading.

Chart 8. Phases of development of an industry during catch-up

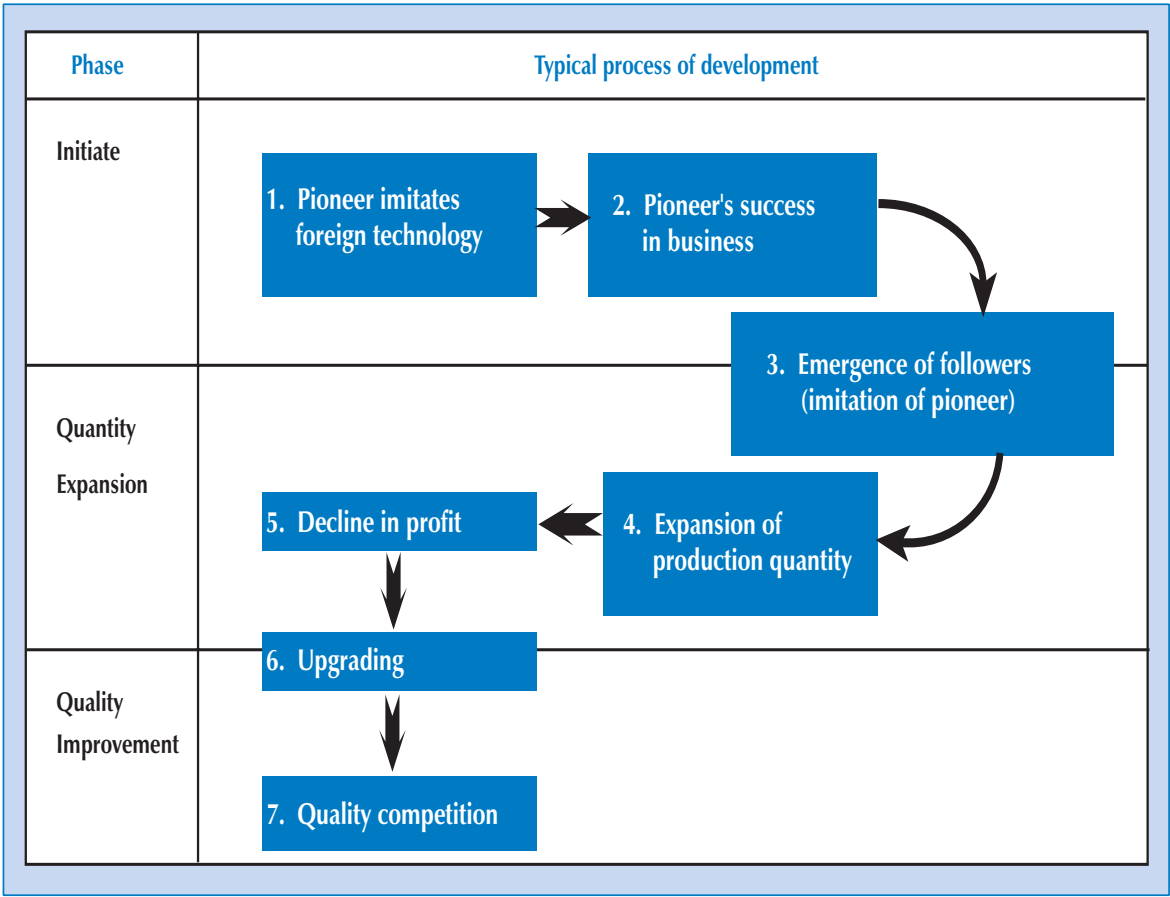

Source: Based on Otsuka (2006). 
From a policy perspective, what is important is that appropriate policies to promote technological learning and innovation are different during the early stage of the catch-up process from the late stage, and different policy measures are required to promote initial acquisition of foreign technology, local diffusion and upgrading. How policy does and should change over time during the catchup process has been most fully elaborated by Linsu Kim on the basis of the case of the Republic of Korea (Kim 1980; Westphal, Kim and Dahlman, 1985; Kim and Dahlman, 1992), and by Morris Teubal, who has sought to generalize on the basis of Israel's experience (Avnimelech and Teubal, 2006, 2008 forthcoming; Sercovitch and Teubal, 2007). Box 2 summarizes how policy changed from the early to the late part of the catch-up process in the Republic of Korea.

The assimilation and absorption of existing technologies involve costs and risks, and their success depends on technological efforts of various kinds and the development of various technological capabilities at the level of the firm and the farm. For agriculture, learning involves inventive adaptation of material inputs to local ecological conditions, often blending knowledge and techniques from elsewhere with traditional knowledge. For industry and services, learning is required to develop tacit technological know-how. Tacit knowledge develops through training, experience and watching. Such tacit knowledge is important because various adaptations are required in establishing and operating new facilities. The development of firm-level capabilities and support systems is thus vital for successful assimilation of foreign technology. ${ }^{3}$

Analysis within East Asia has indicated that, in the early stages of catch-up, the development of production and investment capabilities at the firm level is vital (see table 19). As Dahlman, Ross-Larson and Westphal (1987: 774) succinctly put it: "The central issue of technologically developing countries is not acquiring the capability to invent products and processes. It is acquiring the capability to use existing technology - to produce more efficiently, to establish better production facilities, and to use the experience gained in production and investment to adapt and improve the technology in use. This requires technical and operating

Analysis within East Asia has indicated that, in the early stages of catch-up, the development of production and investment capabilities at the firm level is vital.

Table 19. Elements of production and investment capability

Production capability

Production management - to oversee the operation of established facilities

Production engineering - to provide the information required to optimize the operation of established facilities, including:

- Raw material control - to sort and grade inputs, seek improved inputs

- Production scheduling - to coordinate production processes across products and facilities

- Quality control - to monitor conformance with product standards and upgrade

- Troubleshooting - to overcome problems encountered in the course of operation

- Adaptations of processes and products - to respond to changing circumstances and to increase productivity

Repair and maintenance of physical capital - according to regular schedule or when needed

Marketing - to find and develop uses for possible outputs and to channel outputs to markets

Investment capability

Manpower training - to impart skills and abilities of all kinds

Pre-investment feasibility studies - to identify possible projects and to ascertain prospects for viability under alternative design concepts

Project execution - to establish or expand facilities, including:

- Project management - to organize and oversee the activities involved in project execution

- Project engineering - to provide the information needed to make technology operational in a particular setting, including:

- Detailed studies - to make tentative choices among design alternatives

- Basic engineering - to supply the core technology in terms of process flows, material and energy balances, specifications of principal equipment, plant layout

- Detailed engineering - to supply the peripheral technology in terms of complete specifications for all physical capital, architectural and engineering plans, construction and equipment installation specifications

- Procurement - to choose, coordinate and supervise hardware suppliers and construction contractors

- Embodiment in physical capital - to accomplish site preparation, construction, plant erection, manufacture of machinery and equipment

- Start-up of operations - to attain predetermined norms

Source: $\quad$ Westphal, Kim and Dahlman (1985). 


\section{Box 2. The evolution of technology policy during catch-up: the case of the Republic of Korea}

The Republic of Korea has achieved a phenomenal rate of economic growth and poverty reduction through rapid capital accumulation and technological change associated with employment expansion and rising labour productivity. Technology policies were adopted to accelerate the acquisition of technological capabilities. These policies sought to influence the supply of technology and the demand for technology and to lubricate the linkages between supply and demand. The policies, and their effectiveness, evolved over time in the course of continuous technological change.

During the early stage of catch-up, when domestic firms started developing technological capabilities in relatively simple industries with mature technologies, the most important policies for technology acquisition were implicit policies: both trade policy and financial policy stimulated demand for technology. Trade policy involved a combination of tariff protection to stimulate domestic business start-ups and export promotion to push firms to become internationally competitive, as well as some protection for the domestic machinery industry to enable capital goods to be imported at international prices. The financing of purchases by supplier's credits which carried lower rates of interest than those on the domestic market also increased the attractiveness of capital goods imports. Another factor that was basic to the whole process of technology acquisition, diffusion and upgrading was heavy early investment in human resource development, in addition to encouraging the emergence of large firms (chaebols) which could take advantage of economies of scale as well as take the lead in developing technological capabilities in successively more complex industries.

Public research institutes were set up but played a minimal role in technology development: rather, they helped local firms strengthen their bargaining power in relation to foreign technology suppliers. The Government also encouraged the development of local consulting engineering firms by stipulating that the major contractors for all engineering projects should, if possible, be local firms, with foreign partners as minor participants. In the early stages of catch-up, these engineering service firms did not play a major role in the local diffusion of technology, although inter-firm mobility of personnel was important. The scientific and technological information centre set up by the Government was not very well utilized either, as mature technologies were easily imitated through reverse engineering. The Government also took initiatives to strengthen public-sector research and development by means of tax incentives and preferential financing. However, these measures were broadly ineffective during the early stage of catch-up, as the major technological task was to reverse-engineer mature foreign products. The Ministry of Science and Technology was created, but "its activities were largely ignored by action-oriented ministries that shaped industrial policies in promoting production and exports in labour-intensive mature industries" (Kim and Dahlman, 1992: 441).

In short, in the early stages, "in the absence of demand for technological change, the direct instruments to strengthen the supply of technological capability and to provide linkages [between supply and demand] were ineffective" (Kim and Dahlman, 1992: 445): indirect technology promotion measures, which stimulated demand, were more important.

During the later stages of catch-up, from the 1980s onwards, when firms from the Republic of Korea were importing more complex technologies in medium- and high-tech industries that were in a consolidation phase in the sense that process technologies were still changing rapidly, this situation changed. Policies affecting the domestic supply of technology, and in particular the Republic of Korea's own research and development programme, assumed more importance, and policies to stimulate demand, increase supply and link the two all worked effectively together.

The demand side of technology acquisition and upgrading was stimulated through government procurement. The Government liberalized foreign direct investment and foreign licensing, put more pressure on domestic firms to increase competitiveness through gradual trade liberalization and revised intellectual property laws to pre-empt imitative product development. The Government also established an effective technology transfer centre and technical information centres, which became increasingly popular with users. Measures to promote the development of capital goods producers were also taken (quantitative restrictions, import licensing and domestic content requirements) and this induced local producers to develop technological capabilities to meet the increasing demand for capital goods. Technology extension services were also important for the diffusion of best practices, particularly to small and medium-sized enterprises.

The Government of the Republic of Korea also actively promoted R\&D activities at this stage of catch-up, and achieved a major increase in private-sector R\&D efforts. The instruments used by the Government included: (a) tax incentives (reduced tariffs on imports of R\&D equipment; the deduction of annual non-capital R\&D expenditure and the cost of human resource development from taxable income; accelerated depreciation on industrial R\&D facilities; and a tax credit for investment in R\&D facilities); (b) preferential financing for R\&D activities (from a technology fund within the National Investment Fund, the Industrial Development Fund, the Korea Development Bank's Technology Development Fund, industrial technology funds earmarked specifically for automation and the development of new material, and the Small and Medium Industry Promotion Fund); (c) direct R\&D grants; and (d) venture capital creation. In 1987, preferential financing accounted for 64 per cent of total expenditure on research and development in the manufacturing sector.

Box table 1 summarizes the different roles of the private sector, universities and government research institutes in R\&D activities through the early to late stages of catch-up.

Source: Kim and Dahlman (1992); Kim and Yi (1997). 
Box 2 (contd.)

\begin{tabular}{|c|c|c|c|}
\hline & Initial stage & Intermediate stage & Knowledge-intensive stage \\
\hline Business R\&D & $\begin{array}{l}\text { - Little R\&D investment } \\
\text { - Imitative reverse-engineering } \\
\text { - Limited engineering }\end{array}$ & $\begin{array}{l}\text { - Formative stage } \\
\text { - Advanced reverse engineering } \\
\text { - Development and engineering }\end{array}$ & $\begin{array}{l}\text { - Dominant role in the nation's } \\
\text { R\&D } \\
\text { - Globalization of R\&D } \\
\text { - Research, development and } \\
\text { engineering }\end{array}$ \\
\hline University $R \& D$ & $\begin{array}{l}\text { - Minimal role } \\
\text { - Undergraduate teaching oriented }\end{array}$ & $\begin{array}{l}\text { - Formative stage } \\
\text { - Informal links with industry }\end{array}$ & $\begin{array}{l}\text { - Basic research being } \\
\text { strengthened } \\
\text { - Stronger formal links with } \\
\text { industry }\end{array}$ \\
\hline $\begin{array}{l}\text { Government } \\
\text { research institute } \\
\text { R\&D }\end{array}$ & $\begin{array}{l}\text { - Strengthening industry's bargaining } \\
\text { power in technology transfer } \\
\text { - Training experienced researchers } \\
\text { - Reverse engineering of advanced } \\
\text { technologies } \\
\text { - Leading role in the nation's R\&D }\end{array}$ & $\begin{array}{l}\text { - Expansion of government- } \\
\text { supported research institutes } \\
\text { network } \\
\text { - Incubating experienced researchers } \\
\text { - Leading role in national R\&D } \\
\text { policies }\end{array}$ & $\begin{array}{l}\text { - Leading role in national R\&D } \\
\text { projects } \\
\text { - Technical support for SMEs }\end{array}$ \\
\hline
\end{tabular}

capabilities and also, in particular, design and engineering skills (see Bell, 2007). Successful latecomer firms successively develop more complex technological capabilities and associated organizational and marketing skills. ${ }^{4}$ This begins with simple assembly operation and graduates towards more complex tasks such as process adaptation and R\&D as the firm moves closer towards the technology frontier of leading firms (Hobday, 1995). Relationships with foreign buyers can be an important source of technological learning. In such cases, successful firms graduate over time from original equipment manufacture, to given production specification, to own-design manufacture and finally own-brand manufacture (table 20) ${ }^{5}$.

Over time, technological development through catch-up depends not simply on the deepening of these capabilities at the enterprise level, but also on the widening of these capabilities through their development and application in an increasing variety of economic activities. Typically, as a poor economy gets richer, its economy is likely to become more diversified through the introduction of new sectors of economic activity. Recent research has shown that there is a strong association between the level of sectoral diversification within an economy and its level of per capita income (Imbs and Waczairg, 2003).

In this process, the relative importance of agriculture generally declines as economies develop. There are multiple patterns of economic change. However,

Table 20. Learning trajectories of latecomer firms in East Asia (1950s-1990s): process technology, product technology and marketing

\begin{tabular}{|c|c|c|c|c|c|c|}
\hline \multicolumn{3}{|c|}{ 1950s-1990s - Simple activites } & $\rightarrow$ & $\rightarrow \quad \rightarrow \quad \rightarrow$ & \multicolumn{2}{|c|}{ Complex activites } \\
\hline \multirow{2}{*}{$\begin{array}{l}\text { Marketing } \\
\text { Process } \\
\text { technology }\end{array}$} & \multicolumn{2}{|c|}{ Simple OEM/sub-contracting } & $\longrightarrow$ & $\longrightarrow$ & \multicolumn{2}{|l|}{ OBM } \\
\hline & Simple assembly & Process adaptation & Incremental improvements & Process development & $\begin{array}{l}\text { Applied } \\
\text { research }\end{array}$ & $\begin{array}{l}\text { Process } \\
\text { R\&D }\end{array}$ \\
\hline $\begin{array}{l}\text { Product } \\
\text { technology }\end{array}$ & $\begin{array}{l}\text { Assessment } \\
\text { selection }\end{array}$ & Reverse engineering & Prototype development & $\begin{array}{l}\text { Design for } \\
\text { manufacturing }\end{array}$ & New design & $\begin{array}{l}\text { Product } \\
\text { R\&D }\end{array}$ \\
\hline \multicolumn{7}{|c|}{ Source: $\quad$ Hobday, 1995.} \\
\hline \multicolumn{7}{|l|}{ Note: } \\
\hline
\end{tabular}


accumulated capabilities and experience enable the emergence of more technologically complex and knowledge-intensive activities. Moreover, there is also a strong directionality to the widening of technological capabilities which arises because of dynamic inter-sectoral linkages. These may reflect technological interdependencies among sectors of economic activity in which technological capabilities in one sector can be used in another sector. More important than this, however, is the stimulus for innovation which comes through backward and forward linkages, in which technological change which lowers prices or improves quality in one sector opens new profitable investment and innovation opportunities in the linked activities.

One such development trajectory has been identified in relation to the development of clusters of productive activity associated with the development of natural resources. This sequence of structural change may develop from agricultural farming activities, forestry or mining. The typical pattern of development of a mature production cluster has been described as having four stages:

- Phase 1: The natural resource is extracted and exported with minimum essential processing. Inputs, machinery and engineering services are all imported.

The emergence of hightech industries requires more complex technological capabilities than the other two phases, and it is thus likely to emerge after strong engineering capabilities have been established and these skills built upon.

- Phase 2: Processing export activities are initiated. Import substitution with local production of some inputs and equipment is begun (typically under license for the domestic market). Domestic production engineering capabilities develop.

- Phase 3: Exporting of goods and services originally produced for import substitution purposes (for example, basic machinery for undemanding markets) is begun. More sophisticated processed goods are exported. Engineering services are of domestic origin.

- Phase 4: Processed goods of great variety and complexity, inputs and machinery for demanding markets, design engineering services and specialized consultancy services are all exported.

Another typical pattern of structural change which has been identified involves a transition from primary and light industry to large-scale processing industries (such as steel, cement and petrochemicals), the emergence of a capital-goods sector and its transformation into a key sector, and the emergence of hightechnology industry (Justman and Teubal, 1991). These three types of structural change are not necessarily sequential or all relevant for small countries. A capitalgoods sector can emerge from primary production, and not necessarily stem from the demands of large-scale processing industries. However, the development of the latter provides a strong stimulus to the former. The transformation of the capital goods into a key sector occurs when capital goods industries become the locus of accumulated knowledge and experience in a particular group of technologies, accelerating their diffusion across industries. The emergence of hightech industries requires more complex technological capabilities than the other two phases, and it is thus likely to emerge after strong engineering capabilities have been established and these skills built upon. 


\section{E. Applying the catch-up concept in an $D C$ context: Some strategic priorities}

Policies to promote technological learning and innovation need to be adapted to the specific context of LDCs. They are in the early stage of a process of technological catch-up and are generally at the start of the learning and innovation trajectories which typically occur during catch-up. This has particular implications for both strategic priorities and instruments of STI policy.

Technological catch-up will require a pro-growth macroeconomic framework which can ensure adequate financial resources for sustained technological learning and innovation, as well as a pro-investment climate which stimulates demand for investment. Technological catch-up in LDCs will also require the co-evolution of improvement in physical infrastructure, human capital and financial systems, along with improved technological capabilities within enterprises and more effective knowledge systems supporting the supply of knowledge and linkages between creators and users of knowledge. Improving physical infrastructure, human capital and financial systems is absolutely vital because many LDCs are at the very beginning of the catch-up process and have major deficiencies in each of these areas.

The following statistics stand out from the Least Developed Countries Report 2006:

- Basic human capital is very weak in the LDCs. The average length of schooling for the adult population in 2000 was three years. This is less than half the 2000 average level for other developing countries (7.1 years) and is less than the level of schooling was in other developing countries in 1960. Although the level of formal education in LDCs is almost double the 1980 level, the education gap between LDCs and other developing countries is larger than it was in 1960. In 2002, 34 per cent of the total population aged 15-24 and 41 per cent of the female population aged 15-24 was illiterate.

- Physical infrastructure necessary for modern and mass production is also very weak in the LDCs. In 2003, the level of telephone mainlines and fixed and mobile phones per capita was 11 per cent of the level in other developing countries and 3 per cent of the level in OECD countries. In 2002, electricity consumption per capita in the LDCs was 7 per cent of the level in other developing countries and 1.6 per cent of the level in OECD countries. Only 16 per cent of the LDC population is estimated to have had access to electricity that year, compared with 53 per cent in other developing countries and 99 per cent in OECD countries.

- The domestic financial systems are also very weak and characterized by dualistic and segmented structures. The formal financial system is not working to support long-term productive investment in most LDCs. Between 1980 and 2003, a period in which most LDCs undertook financial liberalization, domestic credit to the private sector stagnated at around 14 to 15 per cent of GDP. In contrast to other developing countries, domestic credit as a share of GDP almost doubled, from 30 per cent to 60 per cent, over the same period.

Without improvement in these foundations for development, it is difficult to see how technological change will take place. But it is important that LDC Governments and their development partners go beyond this. In this regard, it

\section{Policies to promote technological learning and innovation need to} be adapted to the specific context of LDCs. They are in the early stage of a process of technological catch-up and are generally at the start of the learning and innovation trajectories which typically occur during catch-up.

Improving physical infrastructure, human capital and financial systems is absolutely vital because many LDCs are at the very beginning of the catch-up process and have major deficiencies in each of these areas.
But it is important that LDC Governments and their development partners go beyond this. 
In order to ensure poverty

reduction, strategic priorities

of STI policy should be

articulated with a view to

promoting economy-wide

expansion of productive

employment opportunities.

is possible to identify six major strategic priorities for LDCs at the start and early stages of catch-up:

1. Increase agricultural productivity, in particular by promoting a Green Revolution in basic staples.

2. Promote the formation and growth of domestic business firms.

3. Increase the absorptive capacity of the domestic knowledge system.

4. Leverage more learning from international trade and FDI.

5. Foster agricultural growth linkages and natural resource-based production clusters.

6. Upgrade export activities.

In order to ensure poverty reduction, these strategic priorities should be articulated with a view to promoting economy-wide expansion of productive employment opportunities. This means that there is need for technological change in both agricultural and non-agricultural activities. Attention should also be given to innovation in non-tradable activities as well as tradables. As Sachs (2004a, 2004b) has pointed out, the choice of more labour-intensive techniques is much easier for non-tradables than for tradables, as the latter have to be internationally competitive.

\section{Technological advances}

in small-scale agricultural production and trade are often critical in initiating a catch-up process.
Promoting a Green Revolution in basic staples should be a top priority of STI policy in many $L D C s$.

\section{PROMOTING AGRICULTURAL PRODUCTIVITY GROWTH IN BASIC STAPLES}

Agricultural activities are the major source of livelihood in most LDCs and also constitute a significant portion of GDP. Sustainable agricultural intensification is becoming a necessity in more and more LDCs, as rural population density rises and the opportunities for agricultural growth through expansion of the agricultural land area are becoming exhausted. The productivity gaps with other countries also indicate that there are major potentials for income generation through agricultural productivity growth. Technological advances in small-scale agricultural production and trade are often critical in initiating a catch-up process. In this regard, promoting a Green Revolution in basic staples should be a top priority of STI policy in many LDCs.

As has been seen from past experience, the first stage in promoting a Green Revolution should be to establish the basics for agricultural productivity growth (see chart 9). These include: investing in rural physical infrastructure, particularly roads and (where appropriate) irrigation systems; establishing adaptive and experimental research stations; investing in extension; and, where necessary, pursuing land reforms (Dorward et al., 2004). After establishing the basics for a Green Revolution, policies should widen the uptake of the new technology. In order to do so, it is necessary to kick-start markets through government interventions to enable farmers access to seasonal finance and seasonal inputs and output markets at low risk and low cost. This often involves subsidies and also special agencies which provide a bundle of services. The importance of government interventions to kick-start markets is evident in the historical experience of the Green Revolution. However, once farmers become used to the new technologies, when volumes of credit and input demand build up, then the private sector can take over. Such state withdrawal should take place in late catch-up stage, though the Government may start to prepare for this in the later phases of early catch-up.

Getting the agricultural knowledge and information system right is a key ingredient of establishing the basics. It is important that LDCs in very early catch- 
Chart 9. Policy phases to support agricultural transformation in favoured areas

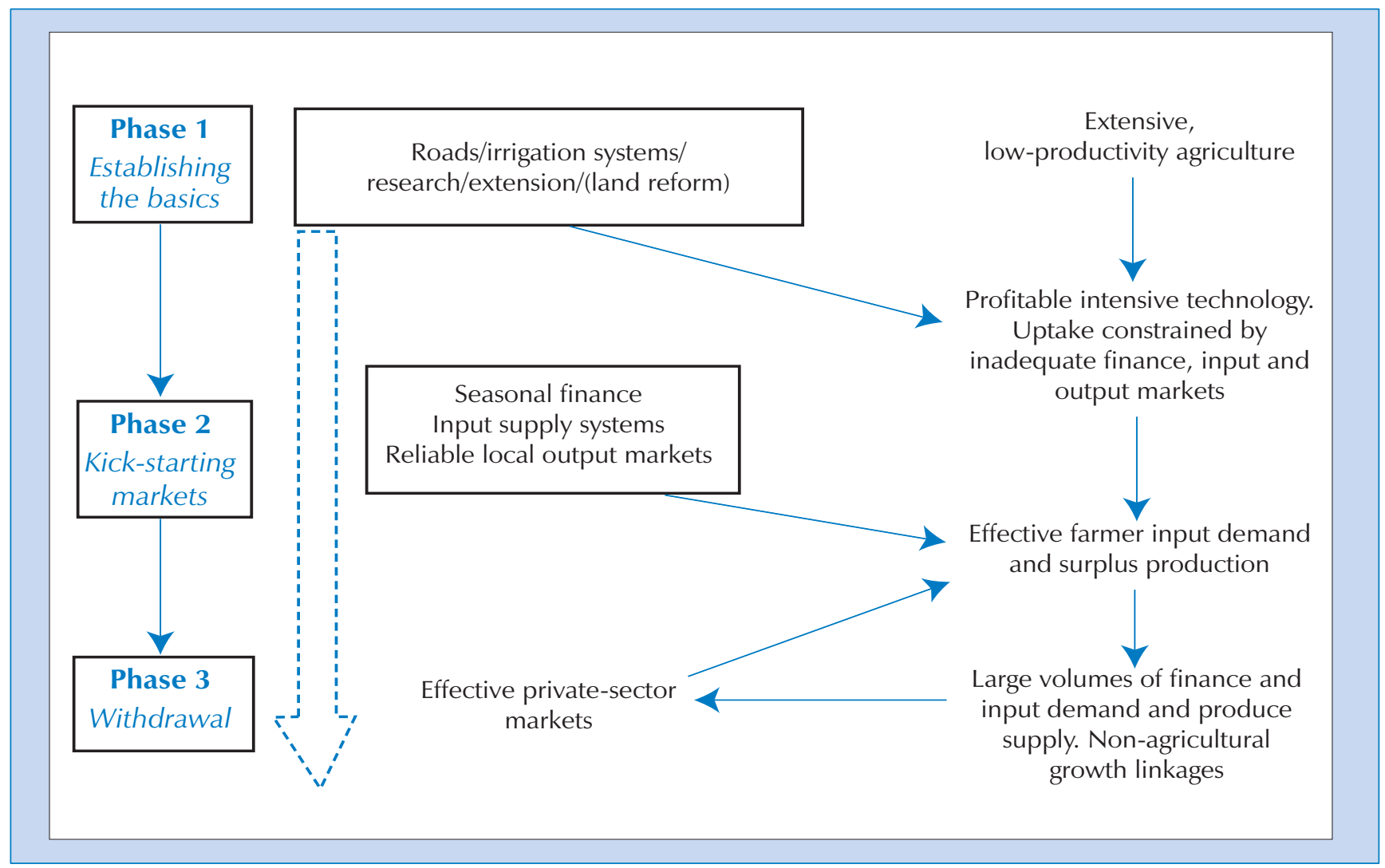

Source: Dorward et al. (2004).

up phase not only develop their adaptive research capabilities for agriculture, but also seek to capitalize on the potentials of the traditional knowledge of farmers. Public research efforts within national agricultural research systems should thus seek to be more closely integrated with farmers' needs and experience. Adaptive research should include development of modern varieties which are suitable for diverse ecosystems and can be integrated into local farming systems. This has in the past proved difficult in Africa. But Otsuka (2004) suggests that it may be possible to promote an organic Green Revolution in East Africa based on organic fertilizer (manure and compost) through keeping cross-bred dairy cows and goats and by using trees with nitrogen-fixing capacity for nutritious fodder. He also suggests that the New Rice for Africa (NERICA), a primarily upland rice, could be developed if rice research programmes were strengthened in West Africa and East and Southern Africa. These programmes could develop second-generation upland NERICA, which would be resistant to pests and diseases, as well as lowland NERICA. Byerlee and Eicher (1997) also indicate the importance of revitalizing maize research capacity for re-energizing Africa's emerging maize revolution. In many countries, agricultural extension systems were expanded through donor support but, as this support has declined, it has been impossible to sustain these systems. This has led to experimentation with different public-private sector mixes in the delivery of extension services. The effectiveness of these experiments is a critical issue which needs close attention (Chapman and Tripp, 2003).

Addressing coordination failures which arise in adoption of new commercial practices requires institutional innovations. In the past, commodity marketing boards were the key institutional innovation which provided multiple functions. They obviously had numerous deficiencies. However, current agricultural market liberalization policies have been premature in most LDCs. They have sought to dynamize rural economies before domestic markets for credit, inputs and technology are adequately established, and even, in some cases before the basic

It is important that LDCs in very early catch-up phase not only develop their adaptive research capabilities for agriculture, but also seek to capitalize on the potentials of the traditional knowledge of farmers. 
Addressing coordination

failures which arise in adoption of new commercial practices requires institutional innovations.

Whereas LDC Governments recognize the importance of promoting technical change in agriculture, there is a general failure to recognize the importance of promoting technological learning and innovation in non-agricultural activities.

At the start of the catchup process, business firm formation is critical for initiating technological learning and innovation. physical infrastructure, research and extension efforts have taken place. The challenge which many LDCs now face is to devise new institutional innovations which can enable the spread of the Green Revolution and which do not fall into the traps of the old marketing boards, but also fill the institutional vacuum which many poor farmers and low-density and remoter regions face.

Broad-based agricultural productivity growth in basic staples - a Green Revolution - is the surest base for substantial poverty reduction. But an important condition for success for such a Green Revolution is that there is a market for increased output. Given the rising rates of urbanization in many LDCs, there is a potential domestic market. However, there is also an increasing tendency for food consumption in LDCs to be met by food imports, including subsidized food imports from rich countries. It may be necessary therefore for LDCs to consider temporary protection in agricultural sectors against subsidized food imports. This should only be temporary and designed to enable the build-up of competitiveness by domestic farmers and the wide uptake of Green Revolution technologies. In successful cases, for example with the introduction of modern varieties of rice in Viet Nam, countries have moved from being a net food importer, to being selfsufficient, to being able to meet domestic demand and also export.

\section{FORMATION AND GROWTH OF DOMESTIC BUSINESS FIRMS}

Whereas LDC Governments recognize the importance of promoting technical change in agriculture, there is a general failure to recognize the importance of promoting technological learning and innovation in non-agricultural activities. But this is an important aspect of sustained development trajectories. Moreover, it is becoming critical in the LDCs because of the growing non-agricultural labour force and the concomitant need to generate productive employment outside agriculture.

At the start of the catch-up process, business firm formation is critical for initiating technological learning and innovation. Business firms are the basic locus of non-agricultural technological learning and innovation, and a major problem facing many LDCs is the lack of such firms. The business sector is characterized by a missing middle. At one end of the spectrum, there are a multitude of informal microenterprises, most of which are characterized by the use of basic and traditional technologies, and cater to the basic consumption needs of restricted and relatively small local markets. At the other end of the spectrum are a few large firms, which are mainly capital intensive, resource based, import dependent or export assembly oriented. These firms are often wholly or minority-owned foreign affiliates or state-owned enterprises. They are not large by international standards but they dominate the business landscape in most LDCs. Between these extremes, there are very few formal-sector SMEs and those small firms which exist do not tend to grow into medium and large firms (UNCTAD, 2006a).

Many informal microenterprises only enable people to subsist. But there are some more dynamic petty activities and their transformation into organized small-scale enterprises can be achieved through "upgrading skills and managerial capacities and improving their managerial capacities and improving their systemic competitiveness through a set of converging affirmative actions such as preferential access to credit, technology and markets" (Sachs, 2004b: 14). Essentially, the key capabilities which are required are building core competences, in particular operating, craft and technician capabilities, as well as business management capabilities. In this regard, technical and vocational education and training can play a key role. 
Collective entrepreneurship can also be a powerful mechanism for both diffusing and upgrading best practices. This can build on existing collective entrepreneurship practices, such as saving and credit rotation associations, or sectoral and territorial groupings of producers and traders who seek economies of scale, e.g. by sharing capital equipment. How collaborative action in the fields of technology, design and marketing can be promoted is a key issue. The encouragement of clusters of activity, e.g. through public infrastructure provision, is likely to be an important field for public policy.

It is important to recognize that whilst informal microenterprises provide an important safety net against destitution for many households, investment and innovation are carried out by formal firms. Moreover, large firms are often more innovative than small firms. Thus, beyond encouraging the transformation of microenterprises into small firms, efforts should be made to ensure that those firms can grow. Fostering linkages between large firms and SMEs can be very important for this process.

\section{INCREASING THE ABSORPTIVE CAPABIUTY OF THE DOMESTIC KNOWLEDGE SYSTEM}

The domestic knowledge systems which constitute the technological infrastructure supporting technological learning and innovation are dualistic and segmented. The production activities which create most employment and livelihoods in the LDCs are based on traditional or indigenous knowledge and traditional knowledge systems. These have great potential as a reservoir of creativity, but are largely de-linked from the modern knowledge systems. The latter, like the formal financial institutions, also have major weaknesses, notably: (a) there are weak linkages within the system between different specialized suppliers of knowledge (national laboratories, research institutes, universities, technology transfer agencies, etc.); (b) knowledge creators are de-linked from the local productive apparatus and creating knowledge on the basis of a R\&Dcentered linear model of innovation rather than responding to demand, which in any case is very weak; (c) the modern knowledge system has often been donordriven; and (d) modern knowledge systems in LDCs are not well connected with international knowledge systems (UNCTAD, 2006a).

Increasing the absorptive capability of domestic knowledge systems requires three major types of policy measure. Firstly, there is a need for education and training which increases the pool of relevant human skills. Secondly, there is a need for incentives to promote the development of technological learning and innovation routines within domestic firms. Thirdly, there is a need for the creation of a set of institutions which increase knowledge linkages among domestic firms, between foreign firms who have invested in LDCs and domestic firms, and between domestic firms and the rest of the world. In the early stage of catch-up, this is likely to involve the creation of specialized, publicly-funded agencies which act as intermediary organizations in various ways, as well as the development of dynamic local clusters of economic activity. However, a long-term goal should be to foster the development of engineering firms, intermediate goods producers and capital goods suppliers. The development of these specialized agents is possible when there is demand for technology services (for example, local technology consultancy firms or engineering contractors).

\section{(a) Human capital and skills}

With regard to education and training, it is important that basic skills related to technology use, operation and maintenance, and business management are

\section{Collective entrepreneurship can also be a powerful mechanism for both diffusing and upgrading best practices.}

The domestic knowledge systems which constitute the technological infrastructure supporting technological learning and innovation in the LDCs are dualistic and segmented.
Increasing the absorptive capacity of domestic knowledge systems is a basic strategic priority. 
strengthened. This requires attention to technical and vocational education and training. But advanced human capital is also very weak in the LDCs. In recent years, tertiary enrolment has been only 6 per cent of the population aged 20 to 24 , compared with 23 per cent in other developing countries. Within tertiary enrolment, the share of enrolments in science and agriculture is approximately the same as in other developing countries, but the share of engineering enrolments is just over half the level in other developing countries (UNCTAD, 2006a). LDCs need to develop their pool of design and engineering skills. This will require enterprise-based learning as well as formal education.

Outmigration of high-skill workers is also a problem in many LDCs. This issue will be taken up in chapter 4 .

\section{It is important that basic skills related to technology use, operation and maintenance, and business management are strengthened.}

\section{(b) Financial incentives for learning and innovative investment}

The second major area of policy to increase the absorptive capability of the domestic knowledge system is the provision of incentives for technological learning and innovation by domestic firms. This goes beyond basic firm formation. Undertaking innovation is a risky and costly activity, and the technological effort entailed in search, acquisition, introduction and upgrading of technology may entail significant sunk costs. As a result the promotion of technological learning and innovation by domestic firms requires financial resources and incentives. As will be discussed in chapter 3, there are major limits to the relevance of IPRs as an incentive mechanism for innovation in the context of catch-up. Indeed, they may have a damaging effect in discouraging informal mechanisms of technology acquisition. Against this background, other incentive mechanisms are important.

Financial incentives are often necessary to endogenize learning routines and dynamic technological capabilities within firms. These are provided in rich countries for R\&D. Moreover, they have been an important instrument in all countries which have successfully pursued a catch-up strategy (see, in particular, Amsden, 2001). They should not be ignored by countries in the early catchup stage. Such incentives have taken various forms, including credit subsidies, various types of fiscal allowances and matching grants for innovation projects. But it is important that their provision is based on competitions and that they are also linked to achievement of certain technological goals. Moreover, the aim of these incentives should be to endogenize learning routines and innovation capabilities in domestic firms so that the financial support is no longer necessary. Box 3 summarizes some key features of innovation funds operating in Nicaragua.

An important issue is what kinds of projects should be supported this way. This should be related to the capabilities one seeks to develop at the firm level. Whereas R\&D in the form of adaptive invention is absolutely vital for agriculture, enterprise-level design and engineering capabilities are much more important during this stage in non-agricultural activities. What matters are capabilities learned through the act of investment. In this regard, financial incentives for pioneer investments may be justified because of their spillover effects.

\section{(c) Increasing linkages in the domestic knowledge system}

Whilst the development of the technological capabilities of domestic firms must be the foundation of efforts to increase the absorptive capability of the domestic knowledge system, it is also important to increase linkages among domestic firms, between domestic firms and foreign firms who have undertaken FDI in LDCs, and also between domestic firms and the rest of the world. At the start of catchup, increasing the linkages in the domestic knowledge system is likely to involve the creation of specialized, publicly-funded agencies, which act as intermediary organizations in various ways, and the promotion of innovative clusters. Later, the 


\section{Box 3. An Innovation Fund for small and medium-sized enterprises: the Nicaraguan example}

Aiming at upgrading domestic innovative capacity and relaxing the constraints faced by small and medium-sized enterprises — notably, high interest rates, short repayment terms and a lack of alternative financing methods - the Nicaraguan Government introduced the Innovation Fund. The Innovation Fund covers three agents: (a) enterprises; (b) technology service providers, such as research and educational institutions and laboratories; and (c) Government policymakers. The relation among these three agents is key to the process of technology diffusion and to the successful working of the fund.

The Innovation Fund is a financing mechanism that provides incentives to SMEs to invest in technological innovations. The incentives, in the form of subsidies, are given to: (a) SMEs (defined as firms with less than 100 employees), where they cover 60 per cent of the cost of the innovation project, up to a maximum of $\$ 30,000$; (b) associations of up to five SMEs, where they cover 80 per cent of the innovation project, up to a maximum of $\$ 100,000$; and (c) technological service providers, where they also cover 80 per cent of the innovation project, up to a maximum of $\$ 100,000$.

The innovation projects financed with the help of these subsidies mainly cover four technology-related areas: (a) technological innovation; (b) innovation in information and communications technologies; (c) organizational innovation; and (d) commercial and market development activities. While the first two areas contain "traditional" innovative activities such as technology upgrading, R\&D design, product development, software development and the management of information systems, the remaining two areas cover new technology-related activities that range from new management models and engineering and associated managerial capabilities to technology acquisition, metrology, the implementation of standards, market research, technological monitoring and participation in international technological fairs.

The role of technological service providers is particularly important as they help small and medium-sized enterprises to identify needs and formulate their technology-upgrading proposals, which are then sent to the Government for approval. After the projects have been submitted to the Government for funding, the SMEs contract the necessary services and purchase the necessary technology and submit a request for reimbursement of the costs incurred. The entire process, from planning to reimbursement, takes an average of 9-12 months.

An ex post analysis of the validity and applicability of the Innovation Fund shows that all the SMEs that received financial support developed new products, new markets and quality control measures. They also introduced new information and communications technology equipment and trained their employees, and expected to see their sales increase.

The Nicaraguan experience shows that Governments have the capacity not only to promote technological innovation but also to stimulate the supply of technological services and specialized technical assistance to SMEs. The SMEs themselves displayed two key qualities: dynamism and flexibility.

In view of the role played by technological service providers, there is a need to facilitate the establishment of technological service centres that provide needs-based services to SMEs — including training, quality controls, designing and engineering capabilities and market studies during the preparatory and maturity phases of the domestic technological upgrading process.

Source: Oyanguren, 2007.

development of domestic specialized technological agents — engineering firms, machinery producers, business consultancy firms - is important.

Public technology centres can play an important role in both stimulating demand and providing technological services before a commercial market for the provision of such services exists. Such centres should stimulate demand from the private sector for developing technological capabilities and assist search and acquisition of technology. As Justman and Teubal (1995: 266) put it in describing the key role of basic technology infrastructure:

"At initial stages of the development of a traditional (low-tech or midtech) industry there may be neither supply nor demand for essential skills, and a cooperative effort may be necessary to articulate the needs of local industry and to elicit a mutual commitment to a path of progressive development. The role of basic TI [technology infrastructure] is to mediate between the technological needs of the industry and potential sources of supply...[It does so] by providing information and advising local industry regarding the availability of foreign technology...stimulating local demand for foreign technology by helping local industry redefine its needs in terms of possibilities that the new technology offers i.e. 'user-need determination';
It is also important to increase linkages among domestic firms, between domestic firms and foreign firms who have undertaken FDI in LDCs, and also between domestic firms and the rest of the world. 
and increasing the effective supply of technology inputs by stimulating investment in adapting them to local needs and promoting local sources of supply (including technical consultants)."

The UNCTAD Centres for Innovation and Enterprise Development provide one example of such agencies (box 4).

One focus of policy action should be to foster the establishment and

One focus of policy action should be to foster the establishment and development of dynamic clusters of firms. Such clusters help to remedy the problem of the "missing middle".

\section{Marketization of basic} technological services and the development of specialized technological agents - engineering firms, intermediate goods producers, machinery producers, business consultancy firms — should be a long-term goal. development of dynamic clusters of firms. Such clusters help to remedy the problem of the "missing middle". Clustering can be considered a major facilitating factor for a number of subsequent developments, including division of labour and specialization, the emergence of a wide network of suppliers, the appearance of agents who sell to distant national and international markets, the emergence of specialized producer services, the emergence of a pool of specialized and skilled workers, and the formation of business associations. These are the so-called external economies deriving from clustering.

These positive developments in cluster do not necessarily take place automatically. Oyelaran-Oyeyinka and McCormick (2007) study several African clusters, and suggest that, although they are all geographically and sectorally bounded groups of producers, some are continuously learning and innovating, while others appear to be trapped in a pattern of poor markets, low-quality products, and lack of imagination. It is therefore the role of policy to foster the establishment of institutions that favour collective action among the firms and institutions of the cluster. This may include supporting the creation of backward ties with suppliers and subcontractors and forward ties with traders and buyers, or within bilateral horizontal linkages between two or more local producers, through joint marketing of products, joint purchase of inputs, order sharing, common use of specialized equipment, joint product development, and exchange of expertise and market information (Nadvi and Schmitz, 1999).

Over time, policy should also seek to build domestic markets for the services associated with technology centres as well as spin off commercially viable innovations to a country. This may not be achieved in the early catch-up phase. But marketization of basic technological services and the development of specialized technological agents should be a long-term goal. These agents - engineering firms, intermediate goods producers, machinery producers, business consultancy firms - are very important for facilitating rapid diffusion of knowledge among producers and their local proximity facilitates adaptation and innovation in ongoing operation and in new investments. Dahlman, Ross-Larson and Westphal (1987) identify the emergence of these agents as a key part of the success of newly industrializing economies, and draw the conclusion that, "It is thus necessary to foster an environment that promotes the formation and growth of local technological agents and their interaction with local users of their services so that technological possibilities are matched to local conditions and requirements in an efficient way" (p.773).

\section{LFVERAGING MORE LEARNING FROM INTERNATIONAL TRADE AND FDI}

As discussed in the previous chapter, international market linkages are not presently functioning well as channels of technological acquisition by domestic firms in the LDCs. Policy action is required to leverage more learning from international trade and FDI. To this end, the following goals should be pursued:

- Strengthening the embeddedness of transnational corporation activity in the domestic economy by stimulating the creation of backward and forward linkages. 


\section{Box 4. Centres for Innovation and Enterprise Development}

Centres for Innovation and Enterprise Development (CIEDs) represent a novel institutional response to the challenge of promoting innovation in manufacturing firms in developing countries. CIEDs constitute an emerging network of change-generating agencies designed to promote technological innovation in manufacturing SMEs and to stimulate the development of networks for innovation among firms and between firms and local knowledge-producing institutions (universities, R\&D institutes, engineering consultancy firms, etc.) In Africa, CIEDs are now operational in Côte d'Ivoire, Ghana, the United Republic of Tanzania, and Zimbabwe.

CIEDs focus mainly on: (a) building and sustaining awareness of the need for innovation; (b) strengthening the ability of firms to identify weaknesses in strategy and operations, as well as bottlenecks in production; and (c) serving as the link between firms and a network of support structures and suppliers who can help firms overcome their problems.

Indigenous small and medium-sized enterprises form the primary clientele of CIEDs. In some cases the latter work with larger firms, especially where such work could promote innovation at the level of small and medium-sized enterprises. CIEDs help their clients to locate appropriate sources of expertise and provide assistance in negotiations and project preparation. Typical projects include: industrial and management audits; work studies and process re-engineering; maintenance management; materials management and sourcing of raw materials, equipment and spare parts; technical training; market analysis for existing or new products; and upgrading product quality to meet local and external market requirements.

The nature of the innovation process - even at the level of the firm - requires very close cooperation between CIEDs and existing business support structures, as well as technology development organizations in each country. At the local level, strategic partnerships will be formed with organizations like Empretec, which have already established strong links with manufacturing enterprises and their associations. Linkages will also be forged with other organizations which have experience in promoting enterprise innovation.

Technology is the main point of departure for engaging with manufacturing firms, and CIEDs work primarily with enterpriselevel personnel to generate and implement innovative solutions to problems encountered within firms. Any external inputs from consultants or experts drawn from the science and technology, R\&D or other institutions in the country are complementary to efforts within the firms. This is a cardinal principle that distinguishes CIEDs from most other business-development service providers and helps to ensure the sustainability of CIED initiatives.

CIEDs' focus on firms helps to stimulate demand for business development services. As firms begin to define their problems and enhance their ability to identify and implement technological innovation projects, they also begin to recognize those resources which must be sourced externally. This helps to strengthen the market for technical and other business development services and also to ensure that such services respond to the real needs of the firms.

In order to improve the learning experience at firm level, participatory approaches to project identification and implementation are used to the fullest extent possible, to ensure that knowledge acquisition and deployment are maximized within the firm. High-impact and lower-cost projects are tackled first so as to minimize financial burdens on firms. Higher-cost projects are phased in gradually as firms build up their internal knowledge and confidence and hence their capacity to handle more capitalintensive activities.

CIEDs seek to generate a continuous process of analysis and action within their client firms. To this end, they use three diagnostic tools at various stages of their interaction with manufacturing firms. The first of these diagnostic tools, known as a change assessment and screening tool (CAST), is designed to help in the selection of potentially innovative firms. The second and third diagnostic tools, known as a general information-seeking tool (GIST) and an in-depth enterprise assessment system (IDEAS), are used to assist firms in analysing their problems and identifying possible solutions.

Source: UNCTAD, 2002.

- Fostering development of SMEs so as to enable them to supply both transnational corporations active in the domestic market and export markets, and to integrate into global value chains.

- Using investment projects in natural resource-based activities (particularly mining) as growth poles by diversifying economic activity vertically and horizontally around one given project.

These goals can be achieved through a series of policy mechanisms, including:

- Negotiating with transnational corporations for commitments on minimum levels of local sourcing. This should be decided on a case-by-case basis, taking into account the supply capacity of domestic firms. In some cases, such

Policy action is required to leverage more learning from international trade and FDI. 
Access to capital goods should be facilitated by reducing their total cost to domestic firms.
South-South links should be actively pursued by LDCS as a means of contributing to national technological catch-up. efforts to establish local sourcing are pursued by transnational corporations themselves or by pressure from international financial institutions that cofinance projects.

- Negotiating with transnational corporation objectives of local further processing of primary products, particularly in the case of natural resource extraction.

- Favouring the establishment of joint ventures with domestic firms when transnational corporations establish themselves in the countries.

- Negotiating with transnational corporations on minimum levels of employment of nationals, so as to foster domestic skills accumulation.

- Imposing training levies and establishing training centres, particularly those related to clusters centering on a given type of activity.

- Providing technical assistance to small firms and farms, in order to raise their awareness on standards (technical, environmental, hygienic, etc.) so as to enable producers to meet higher requirements from domestic and international downstream buyers. This can be done at the cluster level and through collective institutions and joint actions, involving small producers together with buyers, chain leaders and transnational corporations.

- Using public procurement as a means of fostering SME development.

- Supporting the development of national standards infrastructures, especially for certification and testing.

- Establishing stakeholder coordination councils to facilitate strong and horizontal interfaces between all critical economic agents (SMEs, other domestic firms, transnational corporations, and training and research institutions) in the development of industries to connect and coordinate all critical economic agents relevant to upgrading and improving the competitiveness of their activities.

Access to capital goods should be facilitated by reducing their total cost to domestic firms. This can be achieved through trade and fiscal policy mechanisms (e.g. tax rebates, accelerated depreciation, etc.). These types of measures have been part of the mining code reforms adopted in several African countries (see chapter 1, section B of this Report) and should be extended to other sectors, including industry and agriculture.

The increasing share of developing country partners in flows of both trade and FDI of LDCs points to another area of intervention for the purpose of increasing technological capabilities of LDCs. Given the smaller technological distance of LDCs from other developing countries (as compared with developed countries), the impact of technological imports from the latter on LDCs may be higher, as they require less developed domestic absorptive capability. Equally, inflows of FDI from ODCs are likely more conducive to technological learning in host economies. The reasons for this are not only the already-mentioned shorter technological distance, but also the fact that these inflows tend to take more the form of joint ventures with local partners and create more linkages (UNCTAD, 2006b).

South-South links should be actively pursued by LDCs as a means of contributing to national technological catch-up. This may take place in the context of regional integration schemes or through the joint undertaking of supra-national development projects that try to exploit the complementarities of different economies in the same region. 


\section{Promoting diversification through \\ DYNAMIC INTER-SECTORAL UNKAGE EFFECTS}

Besides deepening technological capabilities, a strategic priority of early catchup should be to promote economic diversification through the development of new activities. This should be an essential element of STI policy in LDCs. Diversification can emerge in unexpected ways if policy facilitates entrepreneurial search and discovery in general. But inter-sectoral linkage effects also mean that there are certain economic activities for which supply and demand conditions are likely to be more propitious. In this regard, there are two areas which are particularly appropriate for LDCs. These are: (a) the development of agricultural growth linkages, and (b) the development of natural resource-based production clusters.

\section{(a) Agricultural growth linkages}

In association with promoting agricultural productivity growth, policy should encourage industries and services spurred by agricultural growth linkages. Past experience shows that agricultural growth linkages are a powerful mechanism through which more dynamic informal-sector microenterprises have been transformed into organized small firms. The development of local food processing industries through forward linkages from agriculture is a major mechanism for developing manufacturing experience and skills. Moreover, increasing demand for local consumer goods and simple capital goods, which stems from the rising incomes associated with agricultural productivity growth, provides a major stimulus for microenterprises to transform into small firms. The focalization of physical infrastructure development as well as organizational delivery of public services on market towns can encourage the development of clusters of rural non-farm activities linked to growing agricultural activities.

\section{(b) Natural resource-based production clusters}

Efforts should also be made to develop natural resource-based production clusters through adding value to natural resources and exploring the possibilities for import substitution with local production of some inputs and equipment and the development of domestic production engineering capabilities.

The following measures have been suggested to develop natural resourcebased production clusters:

- Identify, in conjunction with the private sector, the development potential of the activities linked to simple natural resource extraction, including the supply of inputs and equipment, processing activities of growing complexity, and related services, including in particular engineering and consultancy services;

- Identify the activities of the production cluster which require more foreign investment, because of the advanced nature of their technology and their access to international markets, to guide national efforts to attract the most suitable transnational corporations to the country;

- Identify key technologies for developing the production cluster, promote the local mastery and updating of those technologies through selective design and engineering policies and, if necessary, research and development, both in domestic enterprises and in research institutes, and promote the updating and adaptation of technology through missions abroad, licenses, joint ventures and programmes for co-financing consultancy activities in respect of key technologies; and
Past experience shows that agricultural growth linkages are a powerful mechanism through which more dynamic informal-sector microenterprises have been transformed into organized small firms.
Efforts should also be made to develop natural resourcebased production clusters through adding value to natural resources and exploring the possibilities for import substitution with local production of some inputs and equipment and the development of domestic production engineering capabilities. 
Promoting diversification through dynamic intersectoral linkage effects is likely

to require targeted policies

which include financial incentives.
Identify short-, medium- and long-term infrastructural needs of the cluster, including physical infrastructure, science and technology infrastructure and human resources (Ramos, 1998: 124-125).

Promoting diversification through dynamic inter-sectoral linkage effects is likely to require targeted policies which include financial incentives. As the example of the development of the leather industry in Ethiopia shows, it may also involve a complex institutional arrangement involving multiple actors (see box 5).

\section{UPGRADING EXPORTS}

An important feature of most LDCs is the non-dynamic nature of their exports. Thus, a final strategic priority should be upgrading their exports. Technological support for export development requires targeted policies. From past experience, successful cases may be initiated either by Governments who identify potential new opportunities where sustainable comparative advantage can be created, or by entrepreneurs who initiate activities which are new to the country without any initial support from the Government (Chandra and Kolavalli, 2006). However they start, their consequent development is supported by public action to promote both the diffusion and upgrading of technology. These activities may be directed to support traditional agricultural exports, such as cotton or coffee; new niche agricultural products, such as pineapples or cut flowers; labour-intensive industries, such as garments or leather products; or the tourism industry.

There is intense global competition in all these activities, so upgrading is particularly important. One of the most important developing sectors has been garments, and in that sector the trigger for initiating the process has come through trade preferences. This has supported the acquisition of technology and also some diffusion. However, a critical weakness is the lack of upgrading. This threatens the sustainability of these activities.

\section{Box 5. The value chain of the leather goods industry in Ethiopia}

Ethiopia has a comparative advantage in semi-processed leather, finished leather and leather products. The goal of the Ethiopian Government is to make use of this comparative advantage to transform the raw material into finished products.

Box chart 2 summarizes the three main stages of the value chain in the production of finished leather goods, namely, (a) the supply of livestock, (b) tanning and (c) the manufacture of leather products. Growth and competitiveness in the leather sector can only be achieved if the bottlenecks and constraints found at each stage of the value chain are tackled efficiently.

Having the largest livestock population in Africa, Ethiopia has a plentiful supply of raw material: hides and skins have been its second-largest export, preceded only by coffee. The marketing chain for trade in hides and skins stretches from the rural farmer and rural markets to small dealers, town traders and tanneries. The hides and skins produced in slaughterhouses are auctioned to big traders and tanneries. Potential improvements at this stage of the value chain include better preservation and handling of the hides and skins, the prevention of livestock disease, better quality and the introduction of incentive schemes and a pricing structure.

The 1975 ban on the export of raw hides and skins led to an increase in the number of hides and skins processed in Ethiopia. Several new tanneries are currently being built with a view to increasing the production of finished leather. Small and mediumsized tanneries exist alongside large ones. Improvements in quality did not match progress in speeding up the processing of hides and skins during the import-substitution period. Poor manufacturing capabilities, little innovation, heavy indebtedness and poor production capacity are some of the constraints on expansion of manufacturing in this sector.

To improve the learning and technological capabilities of local firms, national actors should intervene to provide services to enterprises and should continuously interact with them. The Ministry of Agriculture initially coordinated all the efforts to make improvements in this sector and checked that Ethiopian standards for hides and skins were met. In 1999, these functions were transferred to the Ethiopian Livestock Marketing Authority, an independent organization. The other agency involved in standard-setting in this area is the Quality and Standards Authority of Ethiopia. Horizontal linkages between these organizations are essential if the value added of the exports of hides and skins is to be increased. Other agencies are responsible for providing incentives: the Ministry of Trade and Industry, for example, is responsible for setting up training institutes to raise the level of 


\section{Box 5 (contd.)}

qualifications of workers in the leather sector, and a "productivity improvement centre" is engaged in training activities and in work to improve quality and upgrade leather-processing techniques. Unfortunately, the centre is not subsidized by the Government and, as a result, is poorly equipped and has only a limited impact.

The leather sector has enormous potential for development. Some key institutions and support structures already exist, but the services provided are not always of very high standard. All improvements in quality and productivity must take place across all stages of the industry's value chain. It is not enough to focus only on upgrading the processing and manufacture of leather for export purposes: the quality of the raw material also needs to be improved.

Box chart 2. Ethiopian leather sector: value chain and existing linkages to support institutions

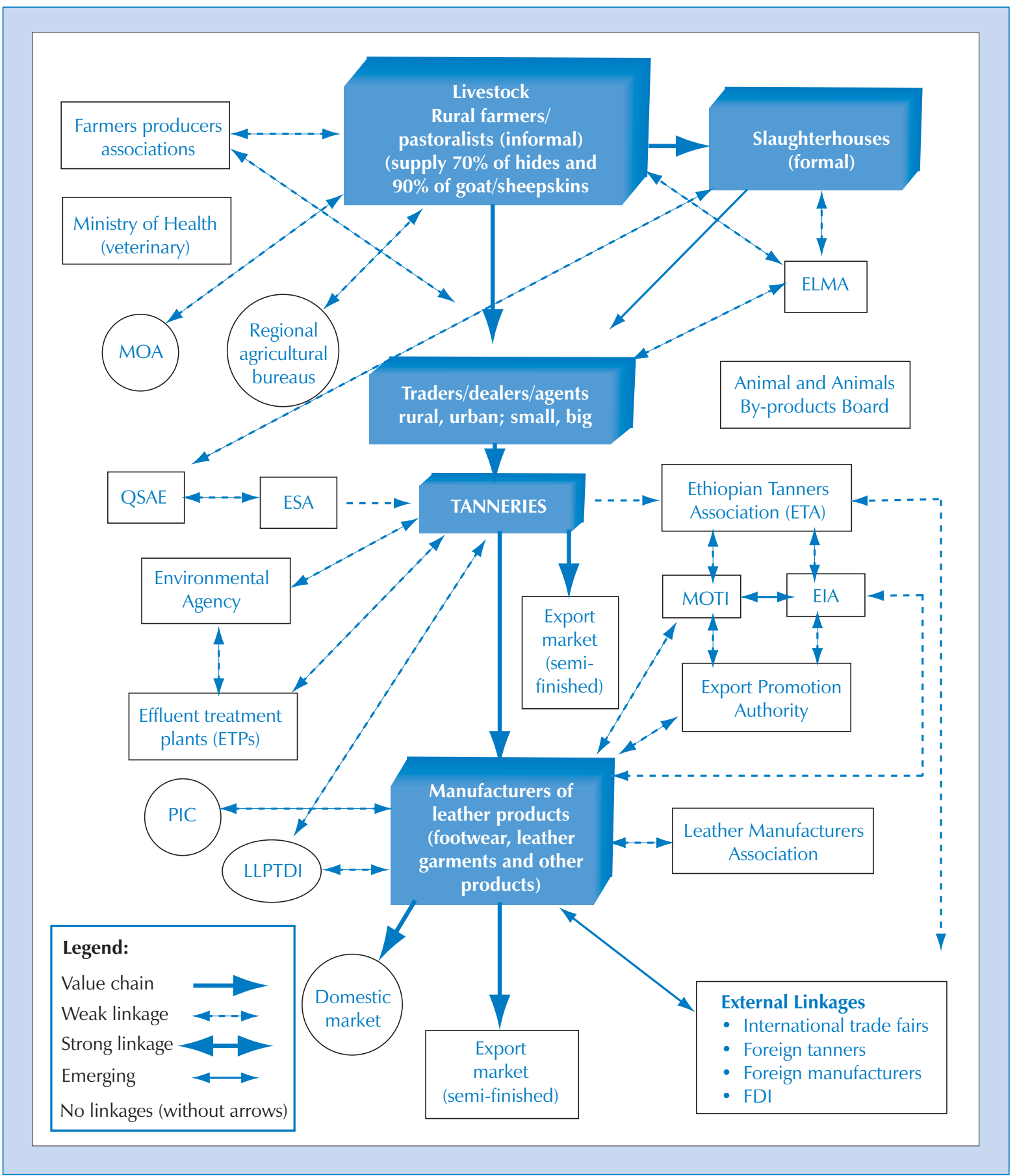

Source: UNCTAD, 2002

Notes: $\quad$ MOA - Ministry of Agriculture; QSAE - Quality \& Standards Authority of Ethiopia; ESA - Ethiopian Standards Authority; MOTI - Ministry of Trade \& Industry; LLPTDI - Leather and Leather Products Training Development Institute; PIC - Productivity Improvement Centre; ELMA - Ethiopian Leather Manufacturers' Association; EIA - Ethiopian Investment Authority. 


\section{F. The question of state capacity}

\section{THE IMPORTANCE OF POUCY LEARNING}

The sceptics would argue that the types of STI policies described above can hypothetically work, but they are inappropriate for LDCs because state capacities are simply too weak. Their formulation and implementation require an effective developmental state and many would argue that this is impossible in an LDC context (see Mkandawire, 2001, for various impossibility theses). Any attempt to design and implement such policies would inevitably lead to massive government failures and make the situation worse.

The problem of state capacity needs to be seen in dynamic rather than static terms.
From a dynamic perspective, just as firms learn over time by doing, Governments also learn by doing. The key to developing state capacity in relation to $S T I$ issues is therefore to develop such capacity through policy practice.
This argument has some substantive basis in that it is true that at present there are major deficiencies in governmental capacity in LDCs, particularly with regard to long-neglected STI issues. Many institutions simply lack the technical and financial means to undertake the tasks that they are mandated to achieve. In this regard, Mozambique is indicative. In 2004, that country's National Standards and Quality Institute had a staff of only 13 people, of which only five had university degrees, and were earning about $\$ 200$ a month. The agency had no laboratory or calibrating facilities. Of the 100 people working at the National Engineering Laboratory, only 10 had university degrees, and most of these held management positions, whilst 15 others had technical secondary education qualifications. On top of the lack of qualified technicians, these institutions are heavily underfunded (Warren-Rodriguez, 2007: 41).

However, the problem of state capacity needs to be seen in dynamic rather than static terms. The static perception that LDCs have weak state capacities ignores the possibility of learning through policy practice. The Republic of Korea and Taiwan Province of China are now regarded as exceptional cases whose exceptionally competent bureaucracies enabled the successful formulation and implementation of catch-up policies. But the Koumintang bureaucracy that initiated and sustained rapid catch-up growth in Taiwan Province of China was notorious for its corruption and incompetence until the 1950s and the Republic of Korea was actually sending its bureaucrats to Pakistan and Philippines for extra training until the late 1960s (Chang and Cheema, 2001). Thus, very successful development experiences did not begin with ideal state capacities.

There is certainly a need to build a highly competent bureaucracy and to build governmental capacity in relation to STI issues, which should encompass human resource development, institution building and adequate financing. But from a dynamic perspective, just as firms learn over time by doing, Governments also learn by doing. The key to developing state capacity in relation to STI issues is therefore to develop such capacity through policy practice.

From this perspective, Teubal (1996) suggests that in relation to innovation and technology policy, there is a policy cycle which must begin with experimentation and search for what works best. As he puts it, "Policy formulation is a gradual process requiring actual experience in implementation (learning by doing). As with innovation, its optimum characteristics cannot be planned initially but must be learned, in part in interaction with the real world" (p.1180). Because it is a process of learning, mistakes are inevitable. But Governments should not be seeking some unique economy-wide optimum but making a smaller set of incremental choices and establishing mechanisms to evaluate outcomes and react to what has been learned. Teubal argues that in the initial infant stage of technology policy, horizontal policies should predominate and that, over time, as 
policy experience is gained, it becomes more possible to successfully implement vertical policies.

The incremental learning approach to policy formulation and implementation should apply to all government policies (Moreau, 2004). But it is notable that with regard to technological catch-up, there are a significant number of models of what works, mainly derived from Japan and East Asian development experience. These models provide a fund of experience which can be drawn on in the learning process. They cannot, of course, be transferred without adaptation to other contexts. But what is significant is that there is a diverse range of experience, including pioneer late industrializers such as the Republic of Korea and Taiwan Province of China, and also followers such as Malaysia, China and Viet Nam. The availability of these policy models for successful catch-up experience contrasts markedly with the lack of models for successful poverty reduction strategies. Governments that are expected to be competent to formulate and implement these poverty reduction strategies, which are policy experiments totally new to the world and without any prior working examples of sustained success, should be expected to be competent enough to formulate and implement policies for technological catch-up.

\section{GovernmenT-BUSINESS RELATIONS}

Government bureaucracy should be competent and independent. But beyond this, an important lesson from successful catch-up experiences is that the Government does not act as an omniscient central planner, but rather formulates and implements policy through a network of institutions which link Government to business. The establishment of intermediary government-business institutions should be a priority in good governance of technological learning and innovation. A good model for this is the deliberation council system established in Japan in the 1950s for the implementation of its industrial policy (see UNCTAD, 1994: part II, chapter 1). This system consisted of a set of industry-specific councils (or boards of enquiry) which consisted of business leaders, former government officials, academics, journalists and representatives from consumer groups, as well as the worlds of labour and finance. Their role was information-gathering, interest coordination and persuasion, and through their operation, policies were not unilaterally decided and enforced by the Government. Such institutions were widely adopted in East Asia in countries seeking technological catch-up, including the Republic of Korea, Malaysia and Thailand (World Bank, 1993: 181-187).

The establishment of government-business links can ensure that the Government has access to information. But it is important that despite this, Government retains its independence. Financial incentives and other forms of support to the private sector must be given on the basis of merit, through competitive selection processes and monitored in relation to specified resultsoriented performance standards. In this framework, governmental support is not a giveaway but rather provided in return for the achievement of results by the private sector which support the achievement of the societal goals embodied in the strategic vision. Amsden (2001) identifies this "reciprocal control mechanism" as the key institutional innovation in successful catch-up. Similarly, Chandra and Kolavalli (2006) show that in all cases of successful establishment of new export industries, Governments played an important role in supporting technological learning and innovation. However, "the practice of providing support to favourite firms within an industry was not followed" (ibid. 16).

Corruption will simply sabotage an effective STI policy of the type discussed here. A basic condition for success is that policies to promote technological 
learning and innovation do not favour or protect special interest groups ("cronyism"). In this regard, it is worth noting that, as well as performance standards and structured competition for government support, the strategic vision plays an important function. It is not simply a coordination framework but also "a conceptual framework for resisting partisan efforts to bend industrial policy in their favour" (Justman and Teubal, 1988: 246). Making the strategic vision explicit is thus very important.

Good governance of technological learning and innovation is likely to require organizational restructuring within the state apparatus itself owing to the cross-sectoral nature of technological learning and innovation.
A final condition for successful design and implementation of policies to promote technological learning and innovation is the existence of national policy space in the sense that Governments have sufficient room to manoeuver to adopt independent economic policies in line with their development objectives.

\section{THE ADMINISTRATIVE ORGANIZATION OF STI POUCY}

Good governance of technological learning and innovation is likely to require organizational restructuring within the state apparatus itself owing to the crosssectoral nature of technological learning and innovation. As a result of this feature, many agencies are required to be involved in promoting innovation (see box 5). Many countries have started to establish ministries of science and technology to take a lead on science and technology issues. But the mere establishment of a ministry of science and technology can be counter-productive, as it can lead to an overemphasis on science and an underemphasis on innovation at the sectoral level (Juma, 2007). Warren-Rodriguez (2007) illustrates well how the crosssectional nature of technological development coupled with inter-ministerial fragmentation of decision-making lead to the marginalization of the science and technology issues in the PRSP action matrix, despite a strong general commitment to technological learning and innovation.

The appropriate organizational structure for integrating technological development issues into policy processes needs careful consideration. One model, suggested by Forsyth (1990: 173) is to have a technology policy unit within the Ministry of Planning (or senior policy coordination unit), together with technology experts in relevant sectoral ministries, including trade, industry, agriculture and education. The technology policy unit should also be in close contact with the ministry of finance with regard to fiscal measures and financial provision of technological activities. Another model is provided by the Nordic countries' approach to innovation policy, such as the establishment of national technology agency and Science and Technology Policy Council in Finland (Nordic Industrial Fund, 2003). Whatever the precise format, this institutional issue must be addressed, once again through a learning approach, as a condition for successful design and implementation of policies to promote technological learning and innovation.

\section{THE IMPORTANCE OF NATIONAL POUCY SPACE}

A final condition for successful design and implementation of policies to promote technological learning and innovation is the existence of national policy space in the sense that Governments have sufficient room to manoeuver to adopt independent economic policies in line with their development objectives. In this regard, there are two critical issues.

Firstly, as they are more aid-dependent, LDCs are much more subject to conditionality or the pressure of expectations on what is regarded as reasonable policy. The PRSP approach aims to enhance domestic ownership, but in practice the tension between conditionality and ownership has not been resolved, and only a few LDCs have started to elaborate home-grown policies. LDC development partners should facilitate experimentation required by the types of STI policies proposed here and facilitate policy learning. This should include improved policy coherence between macroeconomic and microeconomic development 
objectives, as too stringent macroeconomic stabilization may undermine the evolution of the conditions necessary for innovation and learning.

Secondly, whereas the international trade regime may not be highly binding, the international IPR regime is potentially a major problem for technological development in all developing countries seeking to catch-up, including LDCs. This issue is taken up in more detail in the next chapter.

\section{G. Conclusions}

The basic message of this chapter can be summarized in seven basic points.

Firstly, LDC Governments are concerned with promoting sustained economic growth as a basis for poverty reduction, but the treatment of technological change as a source of economic growth is generally weak in their PRSPs.

Secondly, the weak treatment of technological change reflects the marginalization of technology policies within structural adjustment programmes, which have been particularly intensely implemented within the LDCs, the omission of technology issues from the PRSP approach, and the failure to embed PRSPS - which are essentially three-year public expenditure plans - within broader development strategies that include actions to promote technological change. It is vital that LDCs now devise such development strategies. There is widespread restlessness in many developing countries, including LDCs, to find a new, postWashington consensus policy model. A focus on promoting technological change as a sequential, cumulative process can be at the heart of a new approach. Priority actions in three-year poverty reduction strategies can be derived from the broader development strategy. Thus, LDC Governments should integrate an STI policy into their development and poverty reduction strategies.

Thirdly, the STI policy should focus on promoting technological learning and innovation within enterprises, both firms and farms. This is best achieved with a systems model of innovation rather than a linear model which focuses on scientific research and expects that to generate technological development and innovation. It is also best achieved with a mixed market-based approach in which the Government and the private sector work closely together. Public action should facilitate entrepreneurial search and discovery, catalyse private investment and innovation through market-based incentives, and address coordination failures where the profitability of investment depends on interrelated action in different sectors.

Fourthly, the basic strategic objective of STI policy should be to promote technological catch-up with more advanced countries. Successful developing countries have adopted policies to promote technological learning and innovation which are geared towards achieving technological catch-up with more advanced countries. There is no reason why LDC Governments should not do likewise. Indeed, unless the LDCs adopt policies to stimulate technological catch-up with the rest of the world, they will continue to fall behind other countries technologically and face deepening marginalization in the global economy.

Fifthly, policies to promote technological catch-up need to be appropriate to the level of technological development, economic structure and capabilities of the Governments and business sector of the LDCs. Most LDCs are in the early stage of a process of catch-up and are generally at the start of the learning and innovation trajectories which typically occur during catch-up. Technological catch-up in LDCs

\section{LDC Governments should \\ integrate an STI policy into \\ their development and \\ poverty reduction strategies.}
The STI policy should focus on promoting technological learning and innovation within enterprises, both firms and farms.


will require the co-evolution of improvement in physical infrastructure, human capital and financial systems together with improved technological capabilities within enterprises and more effective knowledge systems supporting the supply of knowledge and linkages between creators and users of knowledge. Catch-up involves both the deepening of technological capabilities at the enterprise level and the widening of those capabilities through their development and application in an increasing variety of economic sectors. In that regard, it is possible to identify six major strategic priorities which will be relevant for many LDCs:

- Increase agricultural productivity in basic staples, in particular through promoting a Green Revolution;

- Promote the formation and growth of domestic business firms;

Technological catch-up in

LDCs will require the $\mathrm{CO}^{-}$ evolution of improvement in physical infrastructure, human capital and financial systems together with improved technological capabilities within enterprises and more effective knowledge systems supporting the supply of knowledge and linkages between creators and users of knowledge.
- Increase the absorptive capacity of domestic knowledge systems;

- Leverage more learning from international trade and FDI;

- Foster diversification through agricultural growth linkages and naturalresource-based production clusters;

- Upgrade export activities.

Sixthly, those priorities should be articulated with a view to economy-wide expansion of employment opportunities in order to ensure poverty reduction. That will require technological change in agricultural and non-agricultural activities, and in tradables and non-tradables.

Seventhly, LDC Governments currently have weak capacities to formulate and implement STI policies within development strategies. But this does not mean that such capacities cannot be developed. Governments should adopt an incremental learning approach to policy formulation and implementation. They should also ensure that there is a network of intermediary government-business institutions to ensure good governance of technological learning and innovation. Finally, attention should be given to the administrative organization of STI policy as it is a cross-cutting issue which cannot be left to a ministry of science and technology alone.

\section{Notes}

1 Box, Ulmanen and Steinhauer (2004) reach a similar conclusion in relation to science and technology plans in African, Caribbean and Pacific (ACP) countries. Although the Cotnou Partnership Framework encourages the development of scientific, technological and research infrastructure, science and technology issues are rarely referred to in the Country Support Strategy papers of ACP countries.

2 For further discussion of the state of science and technology in Nepal, see Nepal and Karki (2002). Waast (2002) provides a very revealing discussion on the state of science in Africa, whilst the status of science and technology infrastructure is discussed in Akin Adubifa (2004), Khalil-Timany (2002) and Lall and Pietrobelli (2003).

3 Within LDCs, there are many examples of failures of assimilating and operating transferred industrial technology because of weak firm-level capabilities. The typical symptoms are repeated breakdowns of machinery, a high incidence of down time, low product quality standards, failure to reach rated capacity of equipment, carrying large margins of unplanned excess capacity and excessive unit costs. The causes of these failures include: "(i) the inability to hire labour with the required manual skills; (ii) unforeseen complexity of the process stemming from the failure to make an adequate prior technical appraisal of equipment; (iii) lack of local repair and maintenance facilities; (iv) unsuitability of the process for the assigned task; ( v) failure of machinery manufacturer to provide adequate after-sales service and to supply spare parts when needed; (vi) inherent faults in the equipment; (vii) inexperience of management in organizing and running an industrial operation; and (viii) poor financial appraisal" (Forsyth, 1990: 127). 
4. For further discussion of these technological capabilities, see Lall $(1992,2004)$, UNIDO (2002).

5. Under original equipment manufacture (OEM), the latecomer firm produces a finished product to the precise specification of a foreign buyer. The foreign firm then markets the product under its own brand name, through its own distribution channel and often involves the foreign partner in the selection of capital equipment and the training of managers, engineers and technicians as well as providing advice on production, financing and management.

\section{References}

Akin Adubifa, O. (2004). An assessment of science and technology: Capacity-building in sub-Saharan Africa. ATPS Special Paper Series No. 19, African Technology Policy Studies Network, Nairobi, Kenya.

Akyuz, Y. (1998). East Asian development: New perspectives. Special issue of Journal of Development Studies, 34 (6): 1-137.

Amsden, A.H. (2001). The Rise of "the Rest": Challenges to the West from Late-Industrializing Economies. Oxford University Press, New York.

Amsden, A. and Chu W.W. (2003). Beyond Late Development: Taiwan's Upgrading Policies. MIT Press, Cambridge, Mass.

Arnold, E. and Bell, M. (2001). Some new ideas about research and development. In Partnerships at the Leading Edge: A Danish Vision for Knowledge, Research and Development. Report of the Commission on Development-Related Research, funded by DANIDA, Ministry of Foreign Affairs, Copenhagen.

Arrow, K.J. (1962). Economic welfare and the allocation of resources for innovation. In Nelson, R.R., The Rate and Direction of Inventive Activity. Princeton University Press, NJ.

Avnimelech, G. and Teubal, M. (2006). Innovation and technology policy (ITP) for catchingup: A three phase life cycle framework for industrializing economies. Studies and Perspectives Series No. 69, United Nations Economic Commission for Latin America and the Caribbean, Buenos Aires.

Avnimelech, G. and Teubal, M. (2008, Forthcoming). From direct support of business sector R\&D/innovation to targeting venture capital/private equity: A catching-up innovation and technology policy life cycle perspective. In Economics of Innovation and New Technology, forthcoming, special issue on the governance of technological knowledge, 17 (1).

Biggs, S. and Hatsaert, H. (2004). Strengthening poverty reduction programmes using and actor-oriented approach: Examples from natural resources innovation systems. Agricultural Research and Extension Network Paper No. 134, Overseas Development Institute, London.

Box, L., Ulmanen, J.H. and Steinhauer, N. (2004). Review of science and technology plans in ACP countries. Paper prepared for Technical Centre for Agricultural and Rural Cooperation, Maastricht.

Bell, M. (2007). Technological learning and the development of production and innovative capacities in the industry and infrastructure sectors of the least developed countries: What roles for ODA? Study prepared for UNCTAD as a background paper for The Least Developed Countries Report 2007, UNCTAD, Geneva.

Byerlee, D. and Eicher, C.K. (1997). Africa's Emerging Maize Revolution. Lynne Reinner Publishers, Boulder, $\mathrm{CO}$ and London.

Chandra, V. and Kolavalli, S. (2006). Technology, Adaptation and Exports: How Some Developing Countries Got It Right. World Bank, Washington, DC.

Chandra, V. and Kolavalli, S. (2006). Technology, adaptation and exports: How some countries got it right. Chapter 1 in Chandra, V. (ed.), Technology Adaptation and Exports: How Some Developing Countries Got It Right, World Bank, Washington, DC.

Chang, H.J. and Cheema, A. (2001). Conditions for successful technology policy in developing countries - learning rents, state structures, and institutions. Discussion Paper Series No. 2001-8, UNU-INTECH, Maastricht.

Chapman, R. and Tripp, R. (2003). Changing incentives for agricultural extension: A review of privatized extension in practice. AGRN Network Paper No. 132, Agricultural Research and Extension Network, London.

Cimoli, M., Ferraz, J.C. and Primi, A. (2005). Science and technology policies in open economies: The case of Latin America and the Caribbean. Productive Development Series No. 165, UN-CEPAL, Santiago, Chile.

Dahlman, C.J., Ross-Larson, B. and Westphal, L.E. (1987). Managing technological development: Lessons from the newly industrializing countries. World Development, 15 (6): 759-775. 
Dodgson, M. and Bessant, J. R. (1996). Effective Innovation Policy: A New Approach. International Thomson Business Press, New York.

Dorward, A., Fan, S., Kydd, J., Lofgren, H., Morrison, J., Poulton, C., Rao, N., Smith, L., Tchale, H., Thorat, S., Urey, I. and Wobst, P. (2004). Institutions and policies for propoor agricultural growth. Development Policy Review, 22 (6): 611-622.

ECLAC (1990). Changing Production Patterns with Social Equity. United Nations publication, sales no. E.90.IIG.6, Santiago, Chile.

ECLAC (1995). Latin America and the Caribbean: Policies to Improve Linkages with the Global Economy. United Nations publication, sales no. E.95.II.G.6, Santiago, Chile.

ECLAC (2004). Productive Development in Open Economies. Thirtieth Session of the Economic Commission for Latin America and the Caribbean, 28 June - 2 July, San Juan, Puerto Rico.

Forsyth, D.J.C. (1990). Technology Policy for Small Developing Countries. Macmillan, Houndmills, Basingstoke and London.

Hayami, Y. and Ruttan, V. (1985). Agricultural Development: An International Perspective. John Hopkins University Press, Baltimore, MD and London.

Hobday, M. (1995). Innovation in East Asia. Edward Elgar, Aldershot, England and Brookfield, Vermont.

Imbs, J and Wacziarg, R. (2003). Stages of diversification. American Economic Review, 93 (1): 63-86.

Juma, C. (2007). Speech at the global forum on Building Science, Technology and Innovation Capacity for Sustainable Growth and Poverty Reduction. World Bank, 13-15 February, Washington, DC.

Justman, M. and Teubal, M. (1986). Innovation policy in an open economy: A normative framework for strategic and tactical issues. Research Policy, 15 (3): 121-138.

Justman, M. and Teubal, M. (1991). A structuralist perspective on the role of technology in economic growth and development. World Development, 19 (9): 1167-1183.

Justman, M. and Teubal, M. (1995). Technological infrastructure policy (TIP): Creating capabilities and building markets. Research Policy, 24 (2): 259-281.

Khalili-Timamy, M.H. (2002). State of science and technological capacity in sub-Saharan Africa. ATPS Special Paper Series No. 12, African Technology Policy Studies Network (ATPS), Nairobi.

Kim, L (1980). Stages of development of industrial technology in a developing country: A model. Research Policy No. 9: 254-277. Reproduced in Kim, L. (2000), Learning and Innovation in Economic Development. Edward Elgar, Cheltenham, UK and Northampton, Mass.

Kim, L. and Dahlman, C.J. (1992). Technology policy for industrialization: An integrative framework and Korea's experience. Research Policy, 21 (5): 437-452.

Kim, L. and Yi, G. (1997). The dynamics of R\&D in industrial development: Lesson from the Korean Experience. Industry and Innovation, 4 (2): 2-8.

Klugman, J. (ed.) (2002). A Sourcebook for Poverty Reduction Strategies, 2 volumes, World Bank, Washington, DC.

Kuznetsov, Y. and Sabel, C. (2005). New industrial policy: Solving economic development problems without picking winners. Presentation for the World Bank Institute, 13 June, World Bank, Washington, DC.

Lall, S. (1992). Technological capabilities and industrialization. World Development, 20 (2): 165-186.

Lall, S. (2004). Reinventing industrial strategy: The role of government policy in building industrial competitiveness. G-24 Discussion Paper Series No. 28, UNCTAD, Geneva.

Lall, S. and Pietrobelli, C. (2003). Failing to Compete: Technology Development and Technology Systems in Africa. Edward Elgar Publishing, Cheltenham UK and Northampton, Mass.

Lall, S. and Teubal, M. (1998). "Market-stimulating" technology policies in developing countries: A framework with examples from East Asia. World Development, 26 (8): 1369-1385.

Lele, U. and Ekboir, J. (2004). Technology generation, adaptation, adoption and impact: Towards a framework for understanding and increasing research impact. Working Paper No. 31964, World Bank, Washington, DC.

Melo, A. (2001). Industrial policy in Latin America and the Caribbean at the turn of the century. Research Department Working Paper No. 459, Inter-American Development Bank, Washington, DC.

Melo, A. and Rodriguez-Clare, A. (2006). Productive development policies and supporting institutions in Latin America and the Caribbean. Competitiveness Studies Series, Working Paper No. C-106, Inter-American Development Bank, Washington, DC.

Metcalfe, J. (1995). The economic foundations of technology policy: equilibrium and evolutionary perspectives. In Stoneman, P. (ed.), Handbook of Economics of Innovation and Technology Change. Blackwell, Oxford. 
Mkandawire, T. (2001). Thinking about developmental states in Africa. Cambridge Journal of Economics, 25 (3): 289-314.

Moreau, F. (2004). The role of the state in evolutionary economics. Cambridge Journal of Economics, 28 (6): 847-874.

Nadvi, K. and Schmitz, H. (1999). Industrial clusters in developing countries. Special issue of World Development, 27 (9).

Nelson, R. and Pack, H. (1999). The Asian miracle and modern growth theory. Economic Journal, 109 (457): 416-436.

NEPAD (2005). Africa's science and technology consolidated plan of action. The New Partnership for Africa's Development, South Africa.

Nepal, C. and Karki, B.R. (2002). Promoting business and technology incubation for improved competitiveness of small and medium-sized industries through application of modern and efficient technologies in Nepal. In United Nations Economic and Social Commission for Asia and the Pacific (ESCAP), Promoting Business and Technology Incubation for Improved Competitiveness of Small and Medium-Sized Industries Through Application of Modern and Efficient Technologies, Thailand.

Nordic Industrial Fund (2003). Good practices in Nordic innovation policies. Report produced by STEP Centre for Innovation Research, Oslo.

OECD (1997). National Innovation Systems. Organization for Economic Co-operation and Development, Paris.

OECD (2007). Working party on statistics: Disaggregating technical co-operation. Document DCD/DAC/STAT(2007)3, Organisation for Economic Co-operation and Development, Paris.

Otsuka, K. (2004). Possibility of Green Revolution in Sub-Saharan Africa, in FASID Open Forum XI. The Possibility of a Green Revolution in East Africa, FASID, Tokyo, Japan.

Otsuka, K. (2006). Lecture 1: The economics of industrial cluster. Presentation prepared for Seminar on Cluster-Based Industrial Development, 24 May, Hanoi, Viet Nam.

Oyanguren, R. L. (2007). Nicaraguan Innovation Fund for SMEs: Government instrument to promote exports and national competitiveness by helping businesses to find, adopt and adapt useful technologies. Presentation to the Global Forum on Building Science, Technology and Innovation Capacity for Sustainable Growth and Poverty Reduction, 13-15 February, World Bank, Washington, DC.

Oyelaran-Oyeyinka, B. (2006). Learning to Compete in African Industry: Institutions and Technology in Development. Ashgate Publishing, Aldershot, England and Burlington VT.

Oyelaran-Oyeyinka, B. and McCormick, D. (2007). Industrial Clusters and Innovation Systems in Africa: Institutions, Markets and Policy. United Nations University Press, Tokyo, New York and Paris.

Pack, H. (2000) Research and development in the industrial development process. In Kim, L. and Nelson, R. R. (Eds.), Technology, Learning and Innovation: Experiences of Newly Industrializing Countries. Cambridge University Press, Cambridge, UK.

Peres, W. (2006). The slow comeback of industrial policies in Latin America and the Caribbean, CEPAL Review No. 88, Economic Commission for Latin America and the Caribbean, Santiago.

Ramos, J. (1998). A development strategy founded on natural resource-based production clusters, CEPAL Review No. 66, Economic Commission for Latin America and the Caribbean, Santiago.

Rodriguez-Clare, A. (2005). Microeconomic interventions after the Washington Consensus. Research Department Working Paper No. 524, Inter-American Development Bank, Washington, DC.

Rodrik, D. (2004). Industrial policy for the twenty-first century. Paper prepared for United Nations Industrial Development Organization (UNIDO), Vienna.

Sachs, I. (2004a). From poverty trap to inclusive development in LDCs. Economic and Political Weekly, 39 (18): 1802-1811.

Sachs, I. (2004b). Inclusive development strategy in an era of globalization. Working Paper No. 35, Policy Integration Department - World Commission on the Social Dimension of Globalisation, International Labour Office, Geneva.

Schrank, A. and Kurtz, M. (2005). Credit where credit is due: Open economy industrial policy and export diversification in Latin America and the Caribbean. Politics and Society, 33 (4): 671-702.

Schrank, A. and Kurtz, M. (2006). Open economy industrial policy in Latin America and the Caribbean. Paper prepared for Responding to Globalization in the Americas: the Political Economy of Hemispheric Integration, LSE/ISA, London.

Sercovich, F. and Teubal, M. (2007). Innovation, technological capability and competitiveness: the policy issues in evolutionary perspective. Paper presented at the UNCTAD Meeting of Experts on FDI, Technology and Competitiveness: A Conference in Honour of Sanjaya Lall, 8-9 March, Geneva. 
Singh, R.M. (2001). Development of science and technology in Nepal. Science Technology \& Society, 6 (1): 159-178.

Teubal, M. (1996). A catalytic and evolutionary approach to horizontal technology policies (HTPs). Research Policy, 25 (8): 1161-1188.

Teubal, M. (1997). R\&D technology policy in NICs as learning process. World Development, 24 (3): 449-460.

UN Millennium Project Task Force on Science, Technology and Innovation (2005). Innovation: Applying Knowledge in Development. Earthscan, London and Sterling VA.

UNCTAD (1994). Trade and Development Report 1994. United Nations publication, sales no. E.94.II.D.26, Geneva.

UNCTAD (1995). Strengthening of linkages between the national research and development systems and industrial sectors; Contribution of technologies, including new and emerging technologies, to industrialization in developing countries, E/CN. 16/1995/8, Geneva.

UNCTAD (2000). The Least Developed Countries Report 2000. United Nations publication, sales no. E.00.II.D.21, Geneva.

UNCTAD (2002). Investment and Innovation Policy Review of Ethiopia. UNCTAD/ITE/IPC/ Misc.4, Geneva.

UNCTAD (2004) The Least Developed Countries Report 2004. United Nations publication, sales no. E.04.II.D.27, Geneva and New York.

UNCTAD (2006a). The Least Developed Countries Report 2006: Developing Productive Capacities. United Nations publication, sales no. E.06.II.D.9, Geneva and New York.

UNCTAD (2006b) World Investment Report 2006: FDI from Developing and Transition Economies: Implications for Development. United Nations publication, sales no. E.06. II.D.11, Geneva.

UNESCO (2005). UNESCO Science Report 2005. Paris.

UNIDO (2002). Industrial Development Report 2002/2003. Competing Through Innovation and Learning. Vienna.

Waast, R. (2002). The state of science in Africa: An overview. A survey conducted by the Institut de Recherche pour le Développement, Paris.

Warren-Rodriguez, A. (2007). Science and technology and the PRSP Process: A survey of recent country experiences. Study prepared for UNCTAD as a background paper for The Least Developed Countries Report 2007, UNCTAD, Geneva.

Weiss, L. (2005). Global governance, national strategies: How industrialized states make room to move under the WTO. Review of International Political Economy, 12 (5): 723-749.

Westphal, L.E., Kim, L. and Dahlman, C.J. (1985). Reflections on the Republic of Korea's acquistion of technological capability. Reproduced in Kim, L., Learning and Innovation in Economic Development. Edward Elgar, Cheltenham, UK and Northampton, MA.

Westphal, L.E. (2001). Technology strategies for economic development in a fast changing global economy. Economics of Innovation and New Technology, 11: 4-5.

World Bank (1993). The East Asian Miracle: Economic Growth and Public Policy. World Bank, Washington, DC.

World Bank (2005). Economic Growth in the 1990s: Lessons from a Decade of Reform. World Bank, Washington, DC. 